Tina Ralašić*

Željko Bogdan ${ }^{* * *}$
JEL Classification I31, E71

Pregledni rad

\title{
SREĆA I EKONOMSKA AKTIVNOST
}

U tradicionalnoj ekonomskoj analizi pokazateljima kvalitete života smatra se nekoliko tzv. objektivnih indikatora među kojima se najčešće koristi bruto domaći proizvod (BDP). Međutim, u novije vrijeme javlja se sve više pobornika koji opovrgavaju njegovu prikladnost za praćenje kvalitete života i sreće stanovništva. Stoga ovaj rad prikazuje literaturu koja se bavi istraživanjem veze između sreće i ekonomske aktivnosti. Također se prikazuju nekoliko indikatora kvalitete života i posebno razmatra pozicija Hrvatske unutar njih. Na primjeru Hrvatske su prikazani Hendalov indeks optimizma (HIO) i Nacionalni indeks sreće (NIS) zajedno sa njihovim komponentama koji ne uvrštavaju Hrvate u osobito sretne narode.

Ključne riječi: BDP, indikatori kvalitete života, Easterlinov paradoks, Hendalov indeks optimizma, Nacionalni indeks sreće

\section{Uvod}

U samim temeljima ekonomske teorije koja se izučava na fakultetima susrećemo se sa potrošačem koji bira između košara dobara koje će mu maksimizirati

${ }^{*}$ T. Ralašić, mag. oec. (E-mail: tina.ralai@gmail.com).

${ }^{* *}$ Dr. sc. Ž. Bogdan, docent, Ekonomski fakultet, Sveučilište u Zagrebu (E-mail: zbogdan@ efzg.hr). Bogdan.

Ovaj rad je proizišao iz procesa pisanja završnog rada Ralašić (2015.) čiji je mentor bio Željko

Rad je primljen u uredništvo 20.11.2017. godine, a prihvaćen je za objavu 04.02.2018. 
zadovoljstvo (korisnost) uz danu razinu raspoloživog dohotka. Porast dohotka cee mu omogućiti i da postigne veći stupanj zadovoljstva jer će mu osigurati kombinacije dobara koje mu ranije nisu bile dostižne. U tom tradicionalnom pristupu individualno zadovoljstvo se povezivalo sa kupnjom dobara i usluga pa se i sam raspoloživi dohodak uzimao za mjeru individualnog zadovoljstva, a rast realne plaće čovjeka činio sretnijim. Proširi li se ta spoznaja od pojedinca na cjelokupnu zajednicu, tada se kao glavni indikator uspješnosti neke zemlje nameće bruto domaći proizvod (BDP) (ili neki drugi „srodan“ makroekonomski agregat poput nacionalnog dohotka) i(ili) njegova stopa rasta. Za izračun alternativnih pokazatelja često nema dovoljno pouzdanih podataka, a opet i rangiranje zemalja prema BDP-u (po stanovniku) i tih alternativnih pokazatelja se često drastično ne razlikuje (Bićanić, Deskar-Škrbić i Tuđa, 2013, str. 10). Zbog toga se, a i zbog njegove jednostavnosti, BDP (po stanovniku) najčešce koristi u ekonomskoj analizi iako su ekonomisti svjesni da on nije najidealniji indikator životnog standarda.

Činjenica je da u standardu ljudi i prosperitetu zemlje materijalni faktori imaju značajnu ulogu, ali je također nužno uključiti i subjektivne osjećaje zadovoljstva i sreće jer su i oni povezani sa kvalitetom života. BDP ne govori dovoljno o kvaliteti života i razvoju društva te koje su stvarne potrebe građana a kamo li koliko ih vlast prepoznaje i servisira kroz javne politike (a da se o efikasnosti i ne govori) (Došen i Ralašić, 2010., str. 31). Stoga se u svijetu sve više zagovara novo mjerenje ekonomskog rasta koje, umjesto općeprihvaćenog BDP-a, uključuje i mjerenje kvalitete života. Takav pokazatelj kreatorima ekonomske politike, sociolozima i drugima koji donose odluke pruža uvid u cjelokupnu sliku života jednog naroda. Također je nužno napomenuti da su mnogi oblici blagostanja teško mjerljivi ili uopće nemjerljivi monetarnim pokazateljima. Kvaliteta života je usko povezana sa srećom pa se u recentno vrijeme, kao nova grana ekonomske znanosti, počinje razvijati i ekonomika sreće (engl. Economics of happiness) koja ima sve više pristaša među znanstvenicima te se sve više vodi računa o tome da se provode aktivnosti kojima se može znatno podići razina sreće na pojedinačnoj, ali i na razini cijele društvene zajednice 1 . Premda je to donedavno bilo nezamislivo, napredak u medicini i psihologiji omogućuje vrednovanje sreće kao varijable što će u budućnosti pridonijeti novim istraživanjima i novim spoznajama (Hanson, 2013.). Ona ce dalje rasvjetljavati faktore koji utječu na sreću, ali i kanale kroz koje će zadovoljno stanovništvo utjecati na ekonomsku aktivnost.

1 Jednu od takvih aktivnosti ističe i Yunus (2009.) na primjerima Indije i Amerike, a odnose se na stimuliranje jako malih kredita (do 100 dolara) kojima se može znatno podići razina sreće na pojedinačnoj i društvenoj razini. Ahlin i Jiang (2008.) su razvili teorijski model kojim se može mikrokreditima u većini slučajeva reducirati siromaštvo i potaknuti razvoj. 
Sreća ljudi postaje prvorazredno političko pitanje što stvara potrebu za kreiranjem politika koje će ljude učiniti više sretnima i manje nesretnima (Layard, 2005.). Prva država u svijetu koja je uključila sreću u ekonomske račune je himalajska kraljevina Butan 1970-ih godina za vladavine kralja Jigme Singye Wangchucka (vladao: 1974. - 2006. ${ }^{2}$, ali o tome se počelo voditi računa i u pojedinim zapadnim zemljama ${ }^{3}$. Tako je npr. na summitu G-20 u Pittsburghu krajem 2009. g. zaključeno da bi vlade trebale više koristiti podatke o blagostanju, odnosno kvaliteti života i sreći kako bi bolje razumjele efikasnost ekonomskih politika i državnih proračuna ${ }^{4}$. Slično je ustvrdio i guverner FED-a Bernanke u ljeto 2010. g. upozoravajući da je pored GDP-a važno voditi i računa o sreći i zadovoljstvu životom (Bernanke, 2010.). I istupi dužnosnika drugih zemalja (npr. Camerona prema: Winnett, 2010., Sarkozyja prema: Samuel, 2009. i predsjednika Singapura prema: Wai-kit, 2013.) pokazuju da sreća postaje važno političko pitanje ${ }^{5}$.

Da bi se kreiralo politike koje pozitivno utječu na ljudsku sreću, važno je poznavati i odrednice doživljaja dobrobiti te se u recentno vrijeme pojavio niz istraživanja na tu temu. Ona su pridonijela novim teorijskim i empirijskim spoznajama pa je njihov prikaz postavljen kao prvi cilj ovog rada. Posebice će biti naglasak na rezultatima koji rasvjetljuju vezu između sreće i ekonomske aktivnosti. Naravno, prikazom nije bilo moguće obuhvatiti sve radove pa će fokus biti na onima koji se najčešće spominju u literaturi dok zainteresirani čitatelji dodatnu literaturu mogu pronaći i u popisima referenci koje sadrže ti radovi.

Prikaz literature će također obuhvatiti i radove koji se bave posttranzicijskim zemljama Europe. Jedan od važnih argumenata zašto je važno pratiti doživljaj dobrobiti u tim zemljama se tiče ekonomskih i društvenih promjena povezanih sa padom socijalizma što utječe na njihovu potporu tržišnoj ekonomiji i demokraciji (Hayo i Seifert, 2003.). Dok se u novije vrijeme povećava broj radova koji proučavaju faktore doživljaja sreće u njima, ona su za Hrvatsku još relativno oskudna. Značajni šokovi i velike strukturne promjene u novijoj povijesti kojima je izložena mala hrvatska ekonomija (ratna stradanja, tranzicija gospodarstva, integracija $u$

${ }^{2}$ U Butanu je 70-ih godina prošlog stoljeća osmišljen razvojni koncept zemlje nazvan bruto nacionalna sreća (engl. Gross National Happiness - GNH) kojim se mjeri prosperitet i sreća stanovnika Butana. Osim o sreći vodi se računa i o nacionalnim resursima. O tome više vidjeti npr. u: Došen (2010.) i Ura, Alkire i Zangmo (2014.).

3 Tako su npr. u SAD-u doprinos konstrukciji indeksa sreće su dali Kahneman i Krueger (2006.) te Kahneman i dr. (2006.).

4 Sažetak zaključaka summita u Pittsburghu je dostupan na University of Toronto (2011.).

5 U debati britanskog časopisa The Economist (travanj 2010. g). o prikladnosti BDP-a kao indikatora životnog standarda i gospodarskog napretka $72 \%$ ispitanika smatralo je da je BDP siromašna mjera za poboljšanje životnog standarda (Ralašić, 2015.). Pitanje sreće i zadovoljstva građana je bila jedna od točaka 66. sjednice Generalne skupštine UN 2011. godine (UN, 2011.). Dick i Šubić (2012.) u Deutsche Welle-u također ističu da je blagostanje važnije od gospodarskog rasta. 
europski prostor, globalna gospodarska kriza) sigurno su utjecali na osjećaj sreće hrvatskog pučanstva. Nadalje on je uzajamno povezan i sa demografskim kretanjima jer će se stupanj zadovoljstva životnim uvjetima sigurno odražavati na odluke o iseljavanju i o zasnivanju obitelji i fertilitetu. S druge strane nepovoljne demografske promjene koje se odražavaju u rastu udjela starijeg i smanjenja udjela mlađeg stanovništva sigurno imaju učinke na stupanj sreće u društvu što su već utvrdila i neka istraživanja u drugim zemljama. Analizirajući prema dobnim grupama ona su potvrdila da krivulja doživljaja sreće ima $\mathrm{U}_{\text {oblik }}{ }^{6}$. Sve izrečeno daje dodatnu težinu istraživanju sreće i u Hrvatskoj jer ona, uz ekonomske, pokrivaju i kulturološke, sociološke, psihološke i druge aspekte života pa je, s obzirom na njihovu oskudnost, cilj ovog članka potaknuti ih. U tu svrhu posebno će se pratiti indeks optimizma agencije Hendal (HIO) te Nacionalni indeks srece (NIS).

Namjera rada je upozoriti na važnost kvalitete života u životnom standardu te pratiti indikatore kvalitete života koji će biti povezani sa osjećajem većeg zadovoljstva. Stoga ce se u drugom dijelu ukratko prikazati put koji je doveo do važnosti sreće u ekonomskom rastu, a u trećem pratiti nekoliko indikatora kvalitete života. U četvrtoj se cjelini stavljaju u odnos osjećaj sreće i ekonomske aktivnosti i prikazuju najvažniji radovi koji analiziraju faktore ocjene vlastitog zadovoljstva dok peti dio zaključuje naša razmatranja.

\section{Koncept sreće u ekonomskoj teoriji i analizi}

Koncept ekonomije sreće o kojoj se u recentno vrijeme uvelike raspravlja u znanstvenim krugovima je poznat još od filozofa utilitarista u 18. stoljeću. Kako im i samo ime kaže, oni su se držali načela korisnosti (lat. utilis = koristan), i smatrali da korist odnosno poticanje blagostanja treba biti osnovno načelo i kriterij čovjekova djelovanja. Valja istaknuti da je J. Bentham, kao najpoznatiji utilitarist?, pod blagostanjem smatrao subjektivnu vrijednost koja proizlazi iz potrošnje dobara i usluga. Naravno, nužno je bilo omogućiti i slobodan izbor pojedincu kako bi izabrao ona dobra koja mu daju najveću korisnost (Bayles i Henley(eds), 1989.).

Nasuprot utilitaristima, Robbins (1932.) ustvrđuje da, ako se želi predvidjeti ponašanje nekog pojedinca, treba samo pretpostaviti da ima stabilan skup sklono-

${ }^{6}$ Primjerice za SAD i Ujedinjeno Kraljevstvo vidjeti Blanchflower i Oswald (2004.), a za posttranzicijske zemlje Hayo i Seifert (2003.), Hayo (2007.), Malešević-Perović (2008.) i Humpert (2010.).

Početkom utilitarizma možemo smatrati izdavanje poznatog Benthamovog djela Principles of morals and legislation (1789.). 
sti dok se razina njegove sreće ne mora mjeriti niti treba uspoređivati s drugim ljudima. Prema Robbinsovom mišljenju bit ekonomije je „odnos između postojećih ciljeva i oskudnih sredstava“, a kako nastaju „,iljevi“ ili sklonosti izvan je njezinog djelokruga.

Pod utjecajem biheviorizma, koji se javlja u XIX. st., i u ekonomiji se u prvoj polovici XX. st. počelo smatrati da se ne može proučavati osjećaje drugih ljudi nego njihovo ponašanje, ali se u zadnjih 20 -ak godina ekonomisti počinju vraćati na proučavanje osjećaja i objašnjavanje ljudskih emocija. Kahneman (2011.) ističe da postoje uvjerljivi dokazi da ljudi ne mogu biti racionalni, ali ne namjerava opovrgavati ni samu ideju racionalizma, niti racionalističku prirodu čovjeka ("ljudi ne mogu biti racionalni, ali ih zbog toga ne treba nazivati iracionalnima"). Shodno tome ljudsko se ponašanje ne može dobro opisati primjenom modela racionalnog pokretača. Hanson (2013.) ističe da su nova dostignuća potvrdila da ono što mislimo i osjećamo utječe na sam mozak. Napredak medicinske tehnologije tako omogućuje da se u području bihevioralne ekonomije i sreća prati kao kardinalna varijabla koja se mijenja slično krvnom tlaku i da se uspoređuje među različitim ljudima. Da se sreća može uspoređivati od čovjeka do čovjeka, smatra i Layard (2005.).

Kao što je već ranije naglašeno, tradicionalni pristup veću sreću stanovnika neke zemlje povezuje sa većim BDP-om po stanovniku što je za glavni cilj gospodarstva nametnulo povećanje proizvodnje dobara i usluga. Međutim, u idućem dijelu ovog teksta osvrnut ćemo se na ograničenja upotrebe BDP-a kao pokazatelja kvalitete života, ali i načiniti pregled prikladnijih indikatora koje je razvilo nekoliko institucija.

\section{Kvaliteta života i njeni indikatori}

\subsection{Problem BDP-a kao indikatora kvalitete života}

BDP spada u skupinu tzv. objektivnih pokazatelja dobrobiti kojima se još pridodaju i stope inflacije i nezaposlenosti te saldo bilance vanjske trgovine (FrajmanIvković, Ham i Mijoč, 2014.), ali se među njima BDP najčešće koristi. Prednosti, poput korelacije sa nekim alternativnim indikatorima ili jednostavnosti, već su istaknute, ali on ima i neke svoje mane. Vjerojatno najbolji znak da BDP nije najprikladnija mjera sreće i kvalitete života je što se kvaliteta života može smanjiti čak i kad BDP raste (npr. zbog prometnih gužvi, zagađenja, klimatskih promjena). Postojanje prednosti i mana upućuje na potrebu SWOT analize korištenja ovog 
indikatora za mjerenje napretka koja je preuzeta iz Frajman-Ivković (2016.) i predočena u tablici $1^{8}$.

Tablica 1.

\section{SWOT ANALIZA BDP-A KAO MJERE NAPRETKA}

\begin{tabular}{|c|c|}
\hline Snage (engl. strengths) & Slabosti (engl. weaknesses) \\
\hline $\begin{array}{l}\text { - Jednostavan i univerzalan } \\
\text { - Koristi se u ekonomskoj politici već } \\
\text { dulje vrijeme } \\
\text { - Usporediv u vremenu } \\
\text { - Usporediv u obuhvatu } \\
\text { - Pozitivno koreliran sa nekim } \\
\text { alternativnim mjerama }\end{array}$ & $\begin{array}{l}\text { - One koje su već prepoznate u Sustavu nacionalnih } \\
\text { računa (tj. utjecaj na eksternalije, vanjski događaji, } \\
\text { neekonomski učinci....) } \\
\text { - Područja koja nisu obuhvaćena (tj. crna } \\
\text { ekonomija, dokolica, ljudske slobode....) } \\
\text { - Upitno pokrivena područja (tj. amortizacija, } \\
\text { dohodak stranaca....) } \\
\text { - Metodološki problemi izračuna (tj. struktura } \\
\text { usluga, distribucija dohotka, zdravstveni uvjeti...) }\end{array}$ \\
\hline Mogućnosti (engl. opportunities) & Prijetnje (engl. threats) \\
\hline $\begin{array}{l}\text { - Pokazatelji kojima se prilagođava BDP } \\
\text { - Satelitski računi Sustava nacionalnih } \\
\text { računa } \\
\text { - Naklonost relevantnih institucija }\end{array}$ & $\begin{array}{l}\text { - Rastući troškovi ekonomskog rasta } \\
\text { - Nove mjere koje uključuju održivost }\end{array}$ \\
\hline
\end{tabular}

Izvor: Frajman-Ivković (2016., str. 262).

Da se BDP ne može poistovjetiti sa srećom i dobrobiti, pokazuju i Goossens, i dr. (2007., str. 15). Tako oni ističu da komponente BDP-a osobna potrošnja i neto investicije mogu biti povezane sa ekonomskom dobrobiti, ali na nju utječu i stavke koje nisu dio BDP-a (dokolica, bogatstvo, netržišne aktivnosti). U životne uvjete, uz ekonomsku dobrobit, oni još uključuju i zdravlje. Naposljetku uz ekonomsku dobrobit i životne uvjete na sreću još utječu genetika, obitelj, aktivnosti, prijatelji, zadovoljstvo poslom i društvene veze... Također, neke komponente BDP-a, poput amortizacije ili dijela dohotka kojeg ostvaruju inozemni proizvodni faktori, nisu povezane sa ekonomskom dobrobiti ili srećom (Goossens, i dr., 2007., str. 15). Stiglitz, Sen i Fitoussi (2010.) dodatno ističu da sam BDP nikad neće moći ukazivati na sposobnost neke zemlje da gospodarski rast pretoči u blagostanje. Loše karakteristike BDP-a potiču na razvoj i neekonomskih objektivnih indikatora dobrobiti pa se tako izdvajaju indikatori koji prilagođavaju BDP najčešće kroz

${ }^{8}$ O tome detaljnije vidjeti u radu: Frajman-Ivković (2016.). 
uključivanje okoliša i društvenih faktora te oni koji ga zamjenjuju ili nadopunjuju (tablica 4 u Dodatku) ${ }^{9}$. Za većinu njih postoje SWOT analize koje ovdje izostavljamo, ali ih zainteresirani mogu naći u (Goossens, i dr., 2007.). Osim razmatranja trenutne dobrobiti važno je voditi i o njenom poboljšanju ili održivosti tijekom vremena na što su već upozorili Stiglitz, Sen i Fitoussi (2010.) ${ }^{10}$.

Stiglitz, Sen i Fitoussi (2010.) ističu da postoje i pojedine komponente blagostanja koje su teško mjerljive ili uopće nemjerljive monetarnim pokazateljima. Takvi pokazatelji primjerice mogu biti povezani sa zaštitom okoliša, ravnotežom između rada i slobodnog vremena te općom razinom zadovoljstva i sreće u druš$\mathrm{tvu}^{11}$. Ovo nadalje upućuje na zaključak da je kod praćenja blagostanja objektivne indikatore poželjno proširiti sa subjektivnim indikatorima mjerenja doživljaja dobrobiti pri čemu se najčešće radi o osobnoj procjeni pojedinih komponenata i/ili cjelokupnog doživljaja subjektivne dobrobiti (zadovoljstvo, osjećaj sreće) ${ }^{12}$. Naravno, u odnosu na objektivni, subjektivni pristup je složeniji, ali se zajedničkim djelovanjem obaju pristupa dobiva sveukupna slika društva ${ }^{13}$. Međutim, neka istraživanja o povjerenju u subjektivne podatke o zadovoljstvu životom (npr. Nikolova i Sanfey, 2015.) pokazuju da stariji i oni slabijeg zdravlja, te oni koji žive u manje demokratskim režimima iskazuju sistemski manje razine doživljaja osobnog zadovoljstva.

9 Vidjeti npr. Frajman-Ivković, Ham i Mijoč (2014., str. 12-23) i Schepelmann, Goossens i Makipaa (2010.), ali kompletan popis indikatora je naveden u Bandura (2008.).

${ }_{10}$ Ovdje su izostavljeni indikatori održivog razvoja, ali je o njima više moguće naći u UNECE/OECD/Eurostat (2008., str. 73-82).

${ }^{11}$ Kod zaštite okoliše je zgodno primijetiti da zagovornici slobodnog tržišta danas priznaju da rješavanje problema klimatskih promjena ne treba prepustiti tržištu s obzirom na to da je očigledno kako je očuvanje prirode teško ostvarivo u sustavu u kojem je dominantna vrijednost rast proizvodnje.

${ }^{12}$ U ovom tekstu smo upotrijebili nekoliko pojmova kojima se mjeri kvaliteta života iako nemaju identično značenje. Tako se npr. u psihologiji pojam subjektivna dobrobit (engl. subjective well-being) upotrebljava za individualno vrednovanje pozitivnih ili negativnih utjecaja, sreće ili zadovoljstva svojim životom (Frey i Stutzer, 2002.a). Zadovoljstvo životom je način na koji ljudi izražavaju svoje emocije i raspoloženja te kako doživljavaju buduće smjerove i mogućnosti (Anand, 2016.). Sreću Layard (2005.) definira kao osjećaj koji nastupa onda kada osoba dugo osjeća pozitivne emocije, odnosno kada se osjeća dobro i uživa u životu. Dakle, možemo ju smatrati kao ugodnu emociju tijekom duljeg razdoblja. Kvaliteta života je opća dobrobit pojedinaca i društva uzimajući u obzir negativne i pozitivne karakteristike života. Ona promatra više aspekata zadovoljstva životom poput fizičkog zdravlja, obitelji, obrazovanja, zaposlenosti, bogatstva, religioznih uvjerenja, financijskog stanja i okoliša (Esposito, i dr., 2013). Međutim, u ovom tekstu termine sreća, (subjektivna) dobrobit, zadovoljstvo životom i kvaliteta života koristimo naizmjenično bez obzira na moguće razlike među njima.

${ }^{13}$ O mjerenju subjektivne dobrobiti vidjeti u Dolan, Layard i Metcalfe (2011.), a o individualnoj ekonomskoj dobrobiti i socijalnom blagostanju unutar Sustava nacionalnih računa u Jorgenson i Schreyer (2015.). 
Mjerenje kvalitete života provodi nekoliko svjetskih institucija i organizacija i među indikatorima kvalitete života posebno razdvajamo: indeks razvoja ljudskog kapitala (engl. Human Development Index - HDI), svjetsku bazu sreće Sveučilišta u Rotterdamu, indeks prosperiteta instituta Legatum te izvještaj o sreći UN-a.

\subsection{Indeks ljudskog razvoja}

Indeks ljudskog razvoja izračunava i objavljuje Razvojni program Ujedinjenih naroda (engl. United Nations Development Program - UNDP) počevši od 1990. godine. Njime mjerimo dostignuća u raznim zemljama prema osnovnim pokazateljima kao što su: razina pismenosti, dohodak, životni standard, siromaštvo i životni vijek. On je kompozitni indeks koji se sastoji od tri podindeksa kojima se procjenjuje $^{14}$ :

1. Zdravstveno stanje populacije koje se procjenjuje na temelju indeksa očekivanog trajanja života;

2. Bogatstvo kojim se mjere robe i usluge na raspolaganju, a prati se indeksom dohotka;

3. Obrazovanja (kojim se mjeri sposobnost za postizanje dohotka).

Geometrijska sredina ovih podindeksa je HDI indeks. On poprima vrijednosti od 0.001 do 1 pri čemu veća vrijednost označava i veći stupanj ljudskog razvoja. Prema veličini HDI-a zemlje se mogu razdijeliti na one sa niskim $(H D K 0.55)$, srednjim $(H D I \in 0.55,0.70)$, visokim $(H D I \in 0.70,0.80)$ i jako visokim $(H D I \geq 0.80))$ stupnjem razvoja ljudskog kapitala. Većina europskih zemalja, prema slici 1, je sa jako visokim HDI-em jer se u tu skupinu ne ubrajaju jedino Bjelorusija, Bugarska, Srbija, Albanija, Bosna i Hercegovina, Makedonija, Ukrajina i Moldavija.

Među europskim (i svjetskim!) zemljama je najbolja Norveška, a na svjetskoj razini ju slijede Australija i Švicarska. Među članicama EU najbolji rezultat ostvaruje Njemačka (četvrta u svijetu), a najlošiji Bugarska (56. u svijetu). Hrvatska sa HDI-em od 0.82 spada u kategoriju zemalja sa vrlo visokim stupnjem ljudskog razvoja (45. mjesto u svijetu), ali je razina HDI-a manja od prosjeka skupine zemalja sa jako visokim HDI-em koji iznosi 0.878. Primjetno je da se prema visini indeksa nalazi na začelju članica EU zajedno sa Rumunjskom i Bugarskom. Moguće je također promatrati i vrijednosti komponenti HDI-a, ali one nisu predmet ovog rada ${ }^{15}$.

14 O načinu konstrukcije HDI indeksa više vidjeti u UNDP (2016.b).

15 Zainteresirani ih mogu naći na web stranici Razvojnog programa UN-a: www.hr.undp. org. Tako je za 2015. g. očekivano trajanje životnog vijeka u Hrvatskoj je 77.5 godina, a bruto na- 
Slika 1.

HDI EUROPSKIH ZEMALJA ZA 2015. GODINU

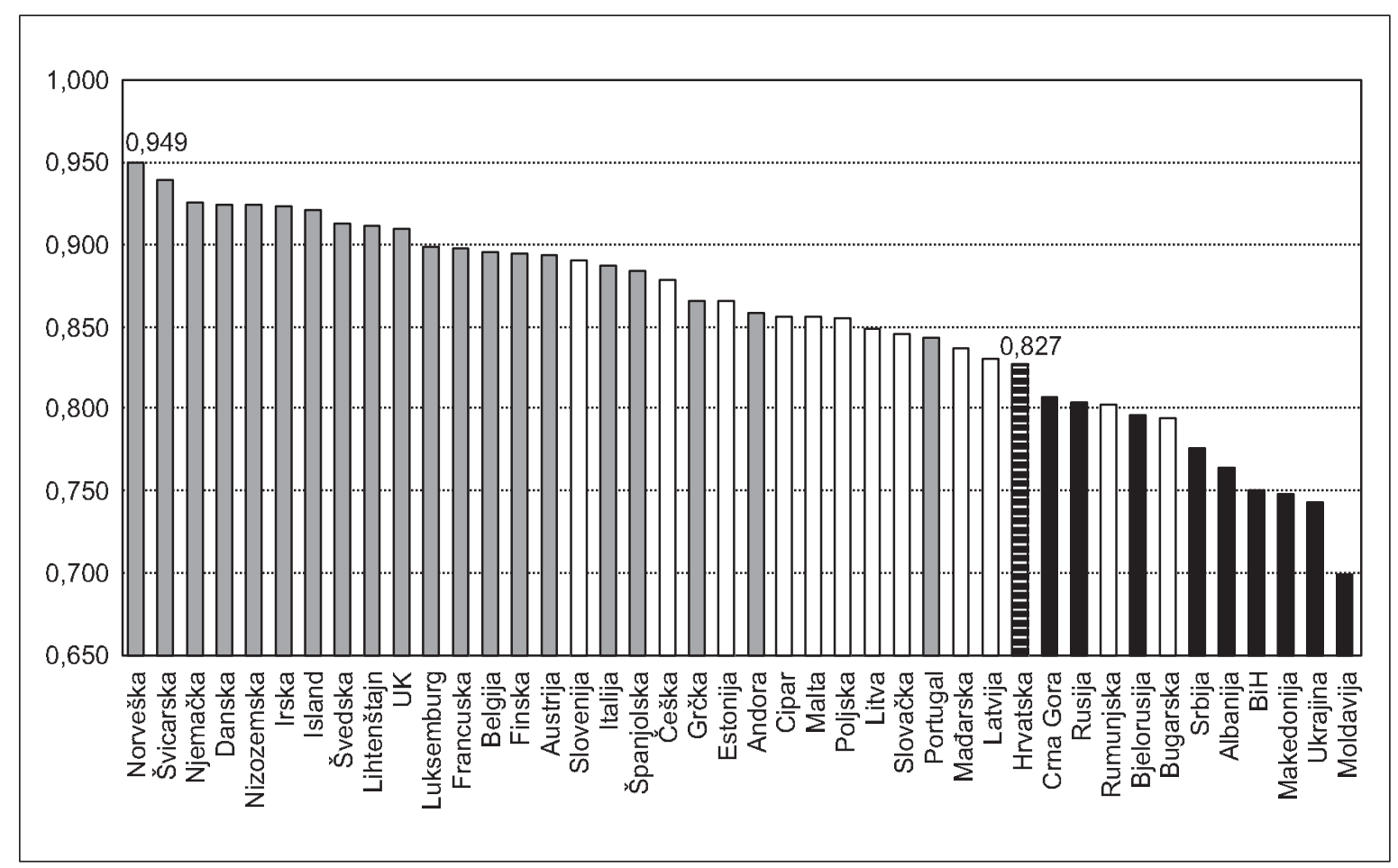

NAPOMENA: Bijeli stupci su nove članice EU (ušle u EU 2004.-2007 g.), crni postranzicijske zemlje koje nisu članice EU dok je Hrvatska posebno izdvojena sa prugastim stupcem. Budući da je članica EU, Cipar se razmatra kao europska zemlja.

Izvor: UNDP (2016.a).

\subsection{Svjetska baza sreće Sveučilišta u Rotterdamu}

Nizozemski znanstvenik Ruut Veenhoven sa sveučilišta Erasmus u Nizozemskoj pokrenuo je osamdesetih godina prošlog stoljeća Svjetsku bazu sreće u Rotterdamu, svojevrsni znanstveni registar o subjektivnom uživanju u životu čije podatke za svoja istraživanja koriste i vodeće svjetske istraživačke agencije poput Gallupa $^{16}$. Ocjene su između 1 i 10 gdje je 10 najveći stupanj sreće. Najsvježiji do-

cionalni dohodak po stanovniku iznosi 20.291 PPP američka dolara. Izvještaj također navodi da se Hrvati prosječno školuju 11.2 godina dok je očekivano trajanje školovanja 15.3 godina.

${ }^{16}$ Izvor za ovaj dio rada bio je Veenhoven (2015.a). Definicije sreće i metode za praćenje sreće koje se primjenjuju kod Svjetske baze sreće dostupne su u Veenhoven (2015.b) i Kalmijn (2015.). 
stupni podaci se odnose na prosječnu ocjenu između 2005. i 2014. godine za 158 zemalja svijeta pa ce se ovdje prikazati rezultati za 40 najsretnijih i 40 najmanje sretnih zemalja u navedenom razdoblju.

Slika 2.

\section{NAJSRETNIJIH ZEMALJA NA SVIJETU PREMA SVJETSKOJ BAZI SREĆE SVEUČILIŠTA ERASMUS (PROSJEČNA OCJENA ZA RAZDOBLJE 2005. - 2014.)}

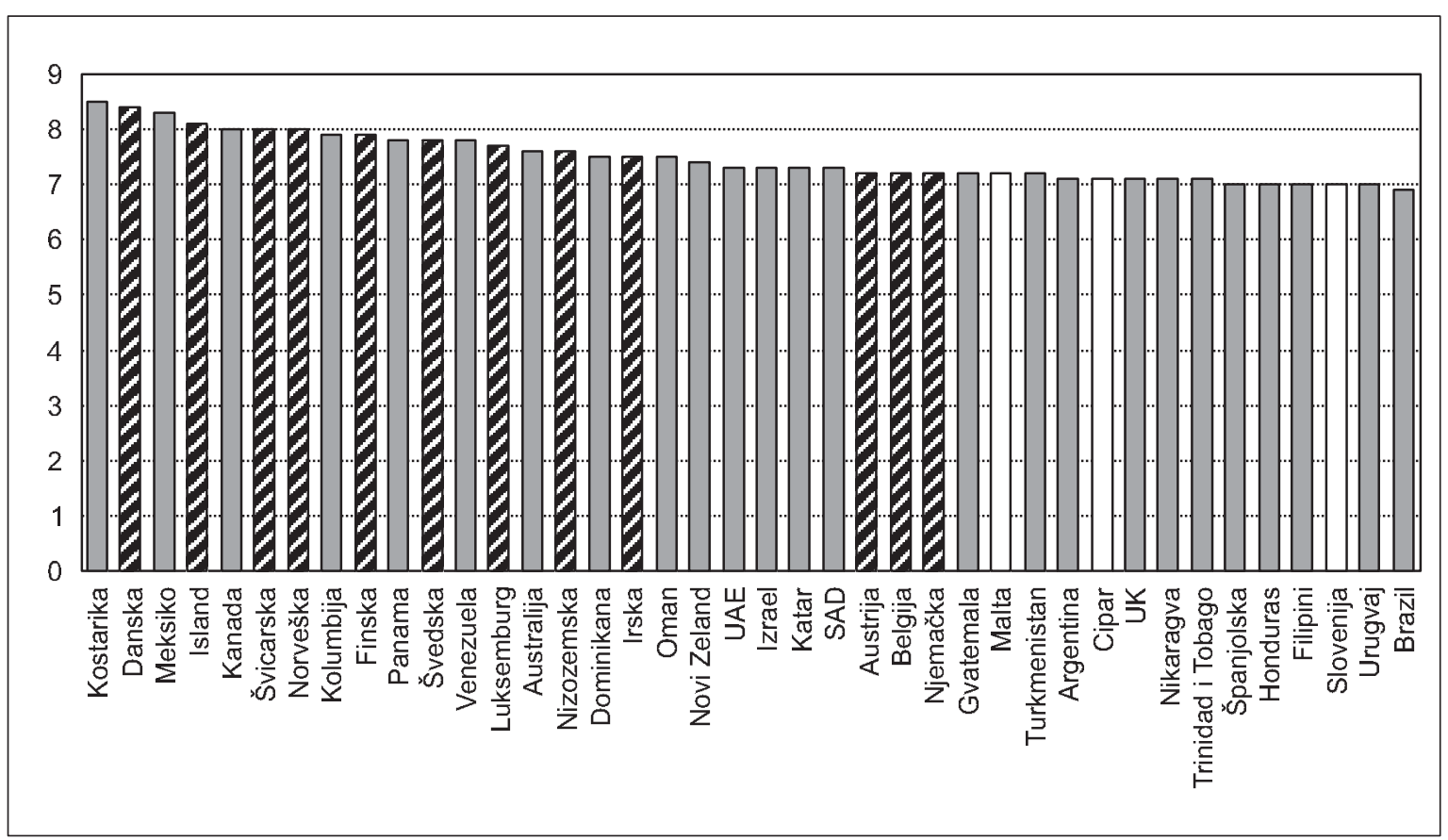

NAPOMENA: Posebno su izdvojene europske zemlje: Bijeli stupci prikazuju nove članice EU (ušle u EU 2004. g. i kasnije), a prugasti stare članice EU (EU-15) i nekoliko najbogatijih europskih zemalja koje nisu u EU (Island, Švicarska, Norveška).

Izvor: Veenhoven (2015.a) .

Sortiranjem ocjena zemalja počevši od najbolje uvidjelo se da 40 najsretnijih zemalja (na slici 2) imaju prosječnu ocjenu od 6.9 naviše. Među njima najsretnija je Kostarika sa prosječnom ocjenom od 8.5. U deset najsretnijih zemalja, osim nje, još ulaze i Danska, Meksiko, Island, Kanada, Švicarska, Norveška, Kolumbija, Finska i Panama. Primjećuje se, također, i da većina članica EU-15 također ulazi u najsretnije zemlje dok se od postsocijalističkih u toj skupini našla samo Slovenija. 
40 najmanje sretnih zemalja imaju prosječnu ocjenu života od 5 ili nižu i nalaze se na slici 3. Najlošija među njima je Tanzanija, ali i među ostalim na slici dominiraju afričke zemlje. Među postsocijalističkim zemljama u navedenoj su skupini samo Bugarska, Makedonija, Albanija, Armenija i Gruzija.

Slika 3.
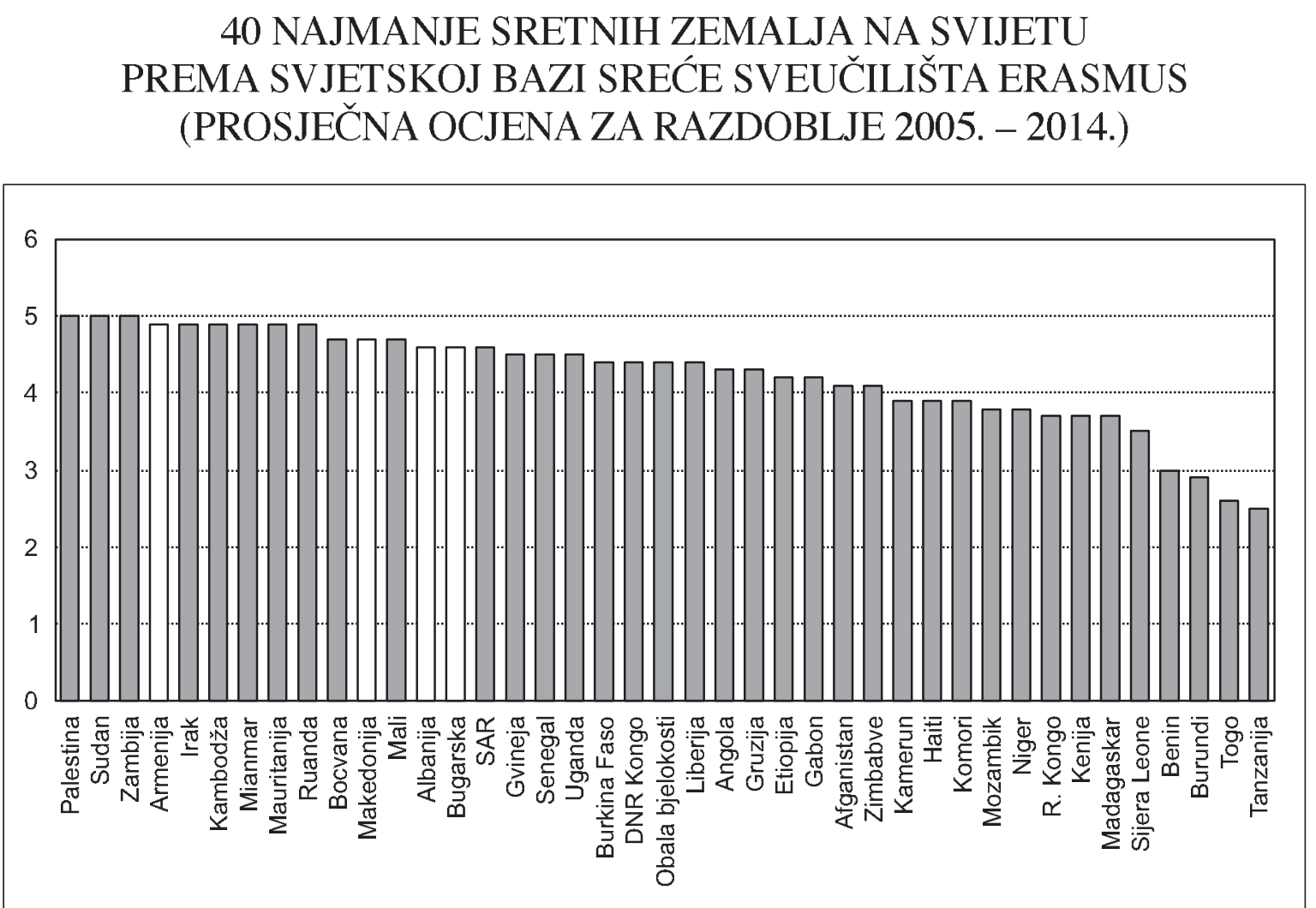

NAPOMENA: Bijeli stupci su postsocijalističke zemlje (Europa + ex SSSR).

Izvor: Veenhoven (2015.a) 
Slika 4.

\section{EUROPSKE ZEMLJE PREMA OCJENI SREĆE \\ PREMA SVJETSKOJ BAZI SREĆE SVEUČILIŠTA ERASMUS (PROSJEČNA OCJENA ZA RAZDOBLJE 2005. - 2014.)}

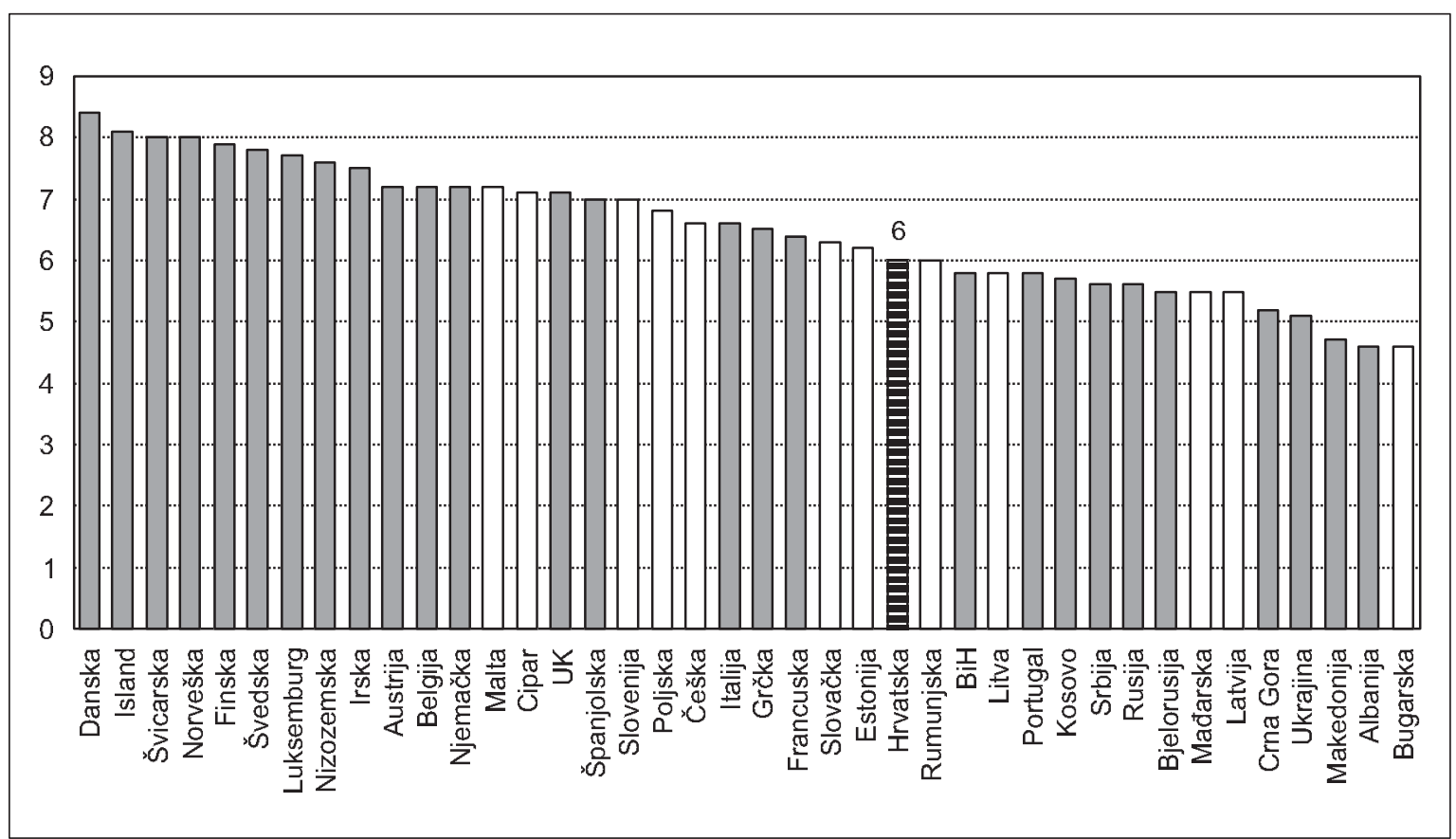

NAPOMENA: Bijeli stupci su nove članice EU (ušle u EU 2004.-2007 g.), a prugasti Hrvatska. Izvor: Veenhoven (2015.a)

Međutim, na navedenim slikama nema ni Hrvatske ni većine europskih postsocijalističkih zemalja pa su na slici 4 u obzir uzete samo europske zemlje. Sam pogled na sliku pokazuje da su, primjerice, ,u prosjeku“ postsocijalističke zemlje manje sretne od članica EU-15. Ali se također može primijetiti da su ,u grupaciji“ postsocijalističkih zemalja i četiri zemlje iz EU-15 (Italija, Grčka, Francuska i Portugal). Hrvatska se, sa prosječnom ocjenom 6, nalazi na 77. mjestu unutar 158 zemalja svijeta, 25. mjestu u zemljama Europe ili na 6. mjestu od 21. postsocijalističke zemlje (iza Slovenije, Poljske, Češke, Slovačke i Estonije). 


\subsection{Indeks prosperiteta ${ }^{17}$}

Britanski institut Legatum je razvio indeks prosperiteta ili indeks blagostanja kojim se procjenjuju zemlje na područjima gospodarstva, poduzetništva, upravljanja, obrazovanja, zdravstva, sigurnosti, osobnih sloboda i socijalnog kapitala. Njihova definicija prosperiteta je ,šansa za svakog pojedinca da istraži, ispuni i podijeli svoj potencijal i time postane najbolje od onog što bi mogao biti“ (Legatum institute, 2016., str. 1). Prema tom pristupu najprosperitetnije nacije nisu samo one koje ostvaruju visok BDP, nego i one čiji su građani sretni, zdravi i slobodni. Sam indeks poprima vrijednosti od 0 do 100 pri čemu veća vrijednost označava i veći prosperitet.

Kao i u prethodnom slučaju odvojeno će se promatrati najuspješnije i najmanje uspješne zemlje svijeta te europske zemlje. Za najuspješnije zemlje su uzete one kojima je indeks jednak ili veći od 65 i tu spada 37 zemalja sa slike 5.54 najmanje prosperitetne zemlje tj. one kojima je indeks manji od 55 su predočene na slici 6 dok slika 7 prati europske zemlje prema stupnju prosperiteta. Prema podacima za 2016. godinu Novi Zeland sa vrijednošću indeksa 79.3 možemo smatrati najprosperitetnijom zemljom na svijetu. Pored nje u 10 najuspješnijih zemalja ubrajaju se: Norveška, Finska, Švicarska, Kanada, Australija, Nizozemska, Švedska, Danska i Ujedinjeno kraljevstvo. Nasuprot njima, u najmanje prosperitetne zemlje ubraja se velik broj zemalja Afrike i nekoliko zemalja Euroazije (Rusija, Moldavija, Bjelorusija, Armenija, Tadžikistan, Azerbajdžan, Ukrajina, Bangladeš, Pakistan, Irak, Afganistan i Jemen) - među njima se sa lošom pozicijom izdvajaju DNR Kongo, Sudan, Srednjeafrička Republika (SAR), Afganistan i Jemen koje su u recentno vrijeme doživljavale visok stupanj političke nestabilnosti i građanske ratove.

Ukoliko se promatraju samo europske zemlje (slika 7), uočit cee se da je Norveška najprosperitetnija, a Moldavija, Bjelorusija i Ukrajina najmanje prosperitetne europske zemlje. Hrvatska se sa 43. mjestom na svjetskoj razini može ubrojiti u srednje prosperitetne zemlje.

${ }^{17}$ Načinjeno prema sadržaju sa web stranice Legatuma: (Legatum institute, 2016.). Metodologija konstrukcije indeksa se može naći u (Legatum_institute, 2016.). 
Slika 5.

NAJUSPJEŠNIJE ZEMLJE SVIJETA PREMA INDEKSU PROSPERITETA INSTITUTA LEGATUM ZA 2016. GODINU

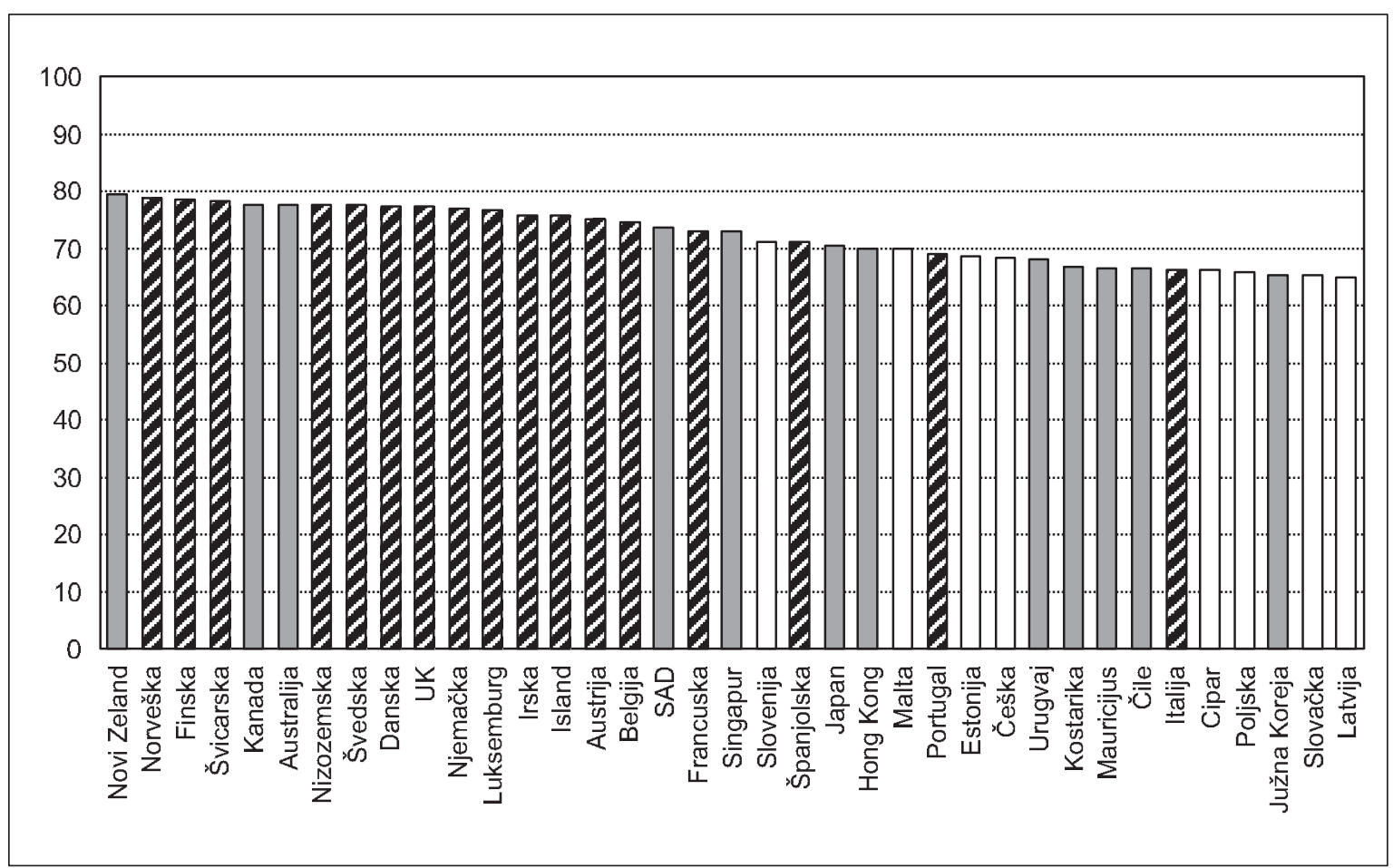

NAPOMENA: Posebno su izdvojene europske zemlje: bijeli stupci prikazuju nove članice EU (ušle u EU 2004. g. i kasnije), a prugasti stare članice EU (EU-15) i nekoliko najbogatijih europskih zemalja koje nisu u EU (Island, Švicarska, Norveška).

Izvor: Legatum institute (2016.). 
Slika 6.

NAJMANJE USPJEŠNE ZEMLJE SVIJETA PREMA INDEKSU PROSPERITETA INSTITUTA LEGATUM ZA 2016. GODINU

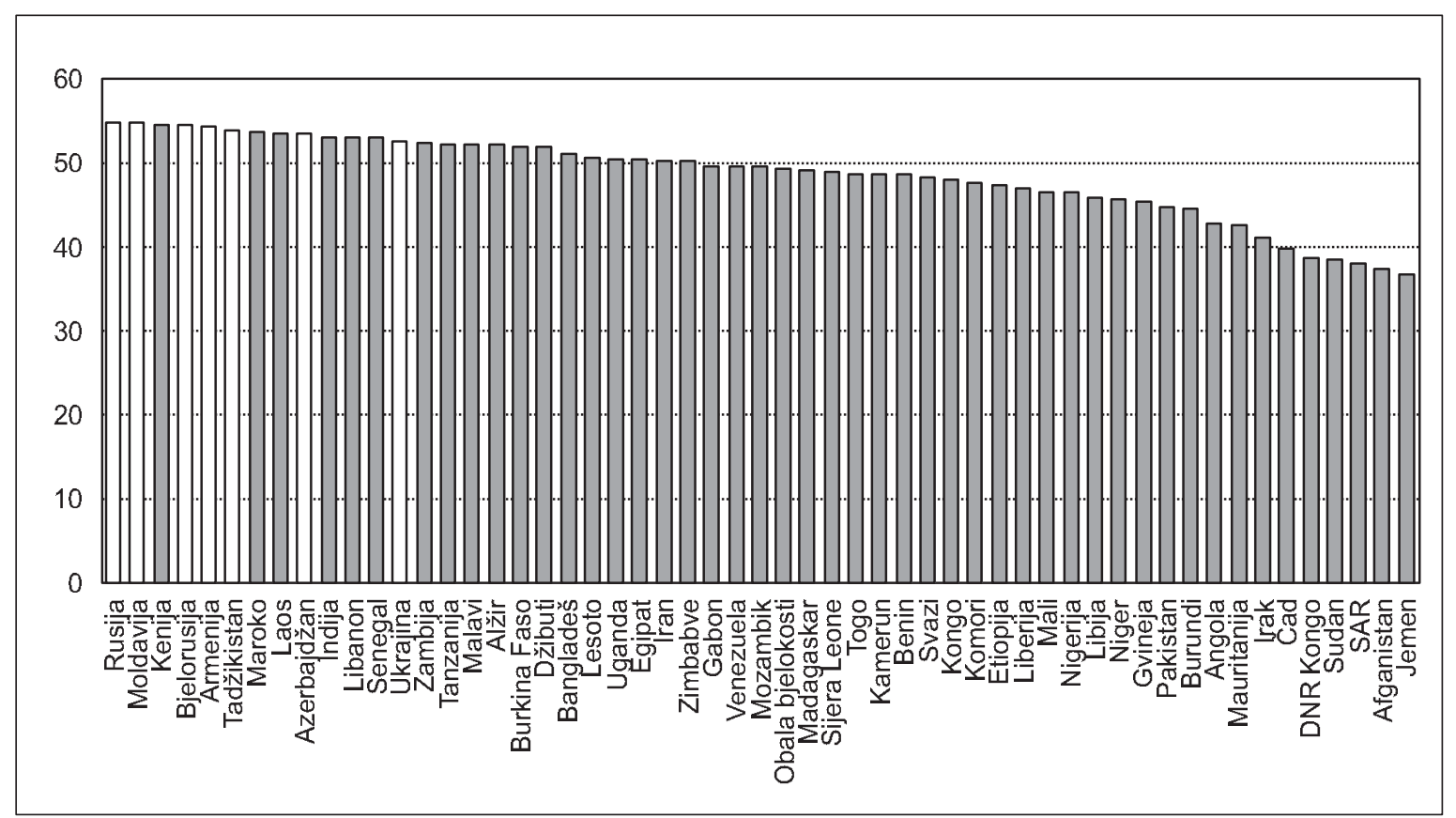

NAPOMENA: Bijeli stupci su postsocijalističke zemlje (Europa + ex SSSR).

Izvor: Legatum institute (2016.). 
Slika 7.

\section{EUROPSKE ZEMLJE PREMA STUPNJU PROSPERITETA U SKLADU SA INDEKSOM PROSPERITETA INSTITUTA LEGATUM ZA 2016. GODINU}

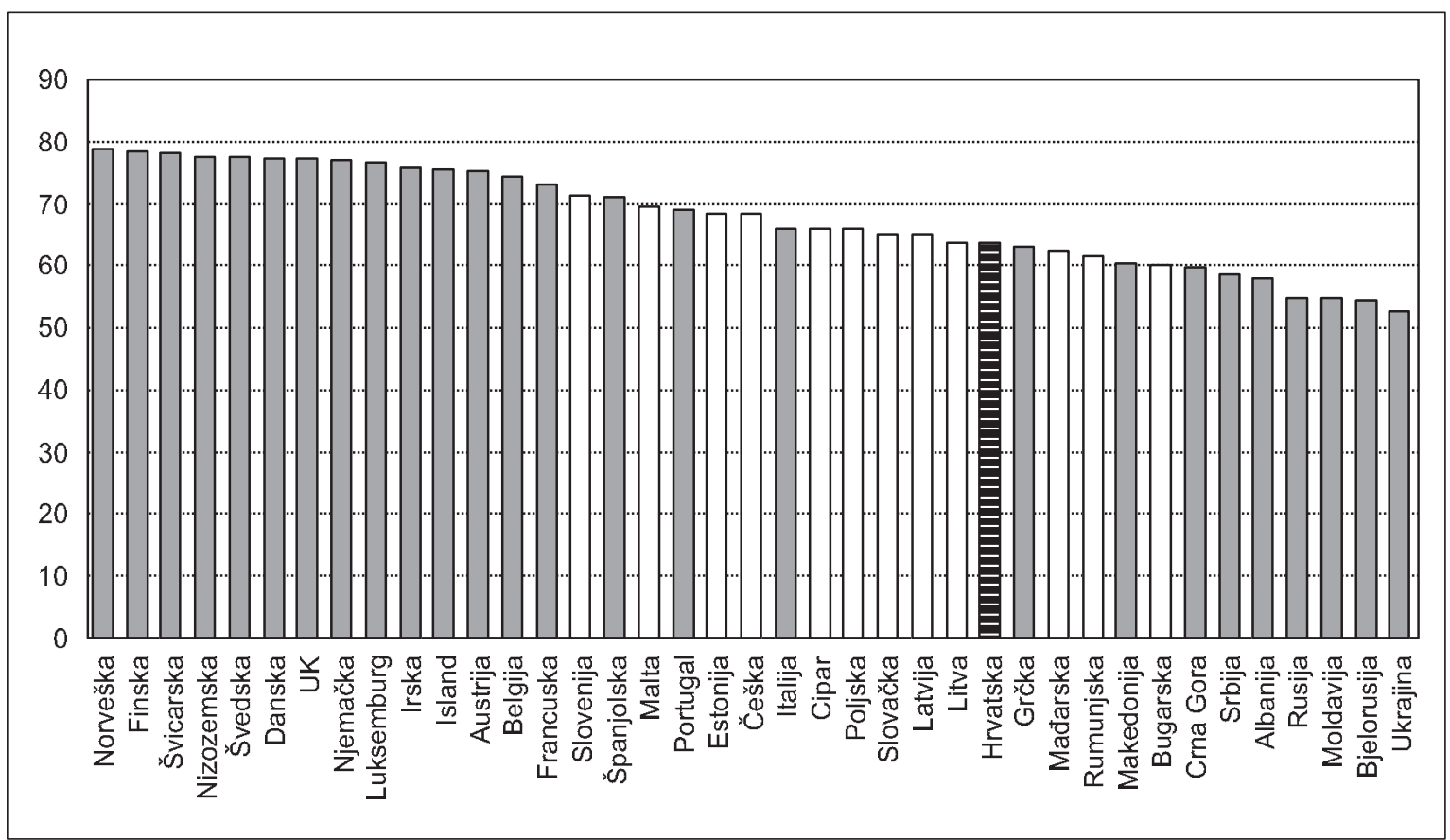

NAPOMENA: Bijeli stupci su nove članice EU (ušle u EU 2004.-2007 g.), a prugasti Hrvatska. Izvor: Legatum institute (2016.).

Sastavnice indeksa jesu: Kvaliteta gospodarstva (gdje se prate otvorenost ekonomije, makroekonomski indikatori, temelji gospodarskog rasta, ekonomske prilike te efikasnost financijskog sektora), Poslovno okruženje (koje uključuje poduzetničko okruženje, poslovnu infrastrukturu, prepreke investicijama i fleksibilnost tržišta rada), Vlada (obuhvaća efikasno upravljanje, demokraciju i političku participaciju te vladavinu prava), Obrazovanje (pristup obrazovanju, kvaliteta obrazovanja i ljudski kapital), Zdravlje (temeljno fizičko i mentalno zdravlje, zdravstvena infrastruktura i preventiva), Nacionalna i osobna sigurnost, Osobna sloboda, Društveni kapital i Prirodno okruženje (kvaliteta prirodnog okruženja, pritisak na okoliš i napori za očuvanje okoliša). Za potrebe ovog rada komentirat ćemo rangove samo za Hrvatsku prema podacima za 2016. g. (valja napomenuti da na rangove utječu i aktivnosti drugih zemalja pa zemlje mogu imati nizak rang čak i uz visoku vrijednost indeksa). Iako rang manji od 50 na svjetskoj razini za pojedine sastavnice (vlada, obrazovanje, sigurnost, osobna sloboda, prirodno okru- 
ženje) i nije loš rezultat, valja naglasiti da se i u najboljim sastavnicama Hrvatska nalazi u donjoj skupini EU-28 ${ }^{18}$.

Slika 8 .

\section{RANGOVI HRVATSKE PREMA SASTAVNICAMA LEGATUMOVOG INDEKSA PROSPERITETA ZA 2016. GODINU}

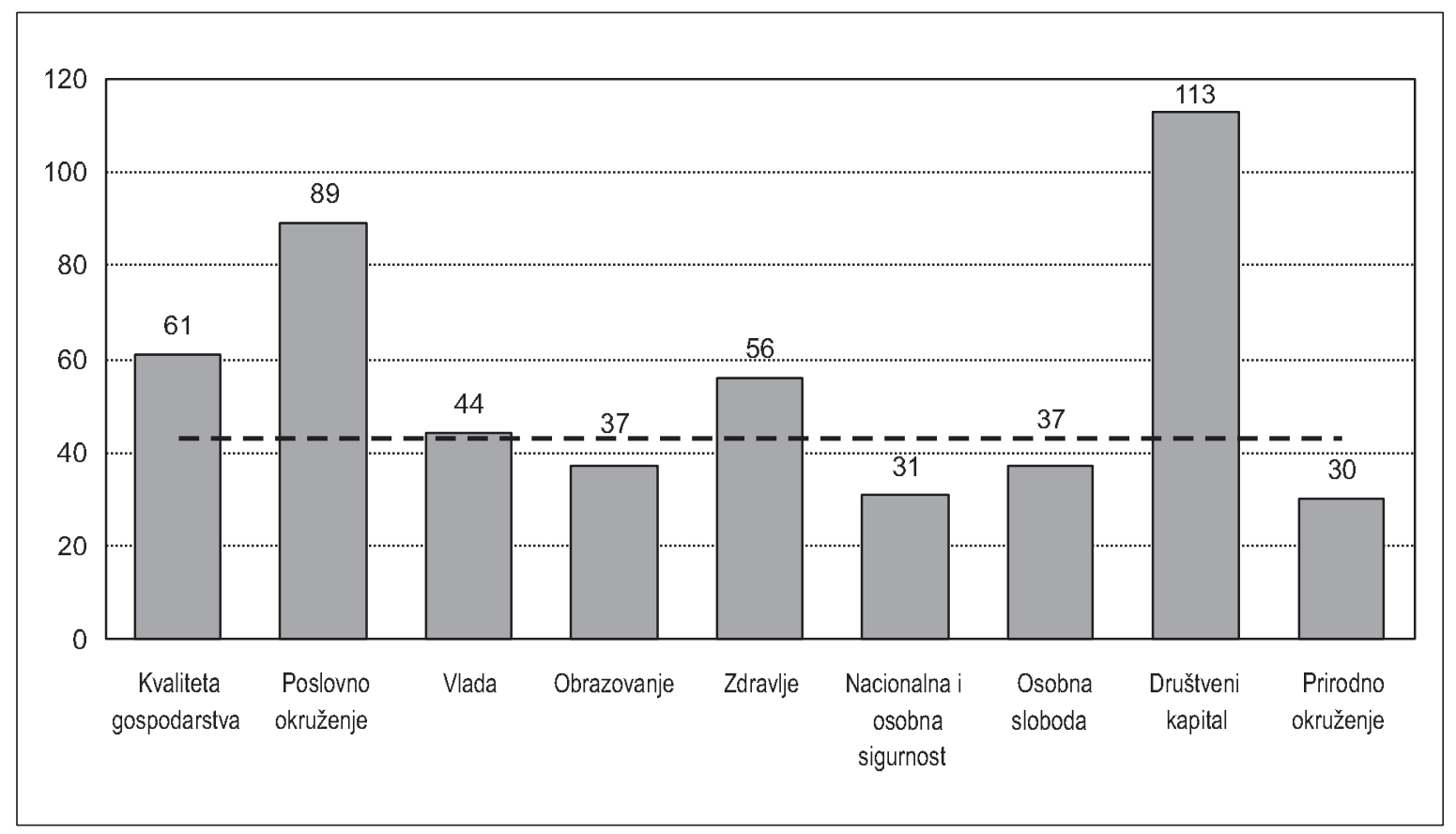

NAPOMENA: Isprekidana linija označava ukupan rang (43.).

Izvor: Legatum institute (2016.)

\subsection{Izvještaj UN-a o sreći u svijetu}

Osim spomenutog HDI-a Ujedinjeni narodi od 2012. svake godine objavljuju Izvještaj o sreći u svijetu (engl. World Happiness Report), ali, za razliku od HDI-a, ovo izvješće uključuje opširnu analizu iz područja gospodarstva, psihologije, zdravlja, BDP-a po stanovniku, percepcije korupcije i solidarnosti sugrađana. Posljednji dostupan izvještaj je za 2017. godinu kojim se utvrđuje prosječna razina sreće između 2014. i 2016. u 155 zemalja svijeta. Ocjena sreće ide od 0 do 10 pri

${ }^{18}$ Zainteresirane za druge zemlje upućujemo na web stranicu instituta Legatum (https:// www.li.com/ i http://www.prosperity.com). 
čemu je 10 najveći stupanj sreće, a 0 njeno potpuno odsustvo i prema nazivu publikacije zvat ćemo ju indeks svjetske sreće (engl. World happiness index-WHI) ${ }^{19}$.

Prikaz podataka je pravljen na sličan način kao i u cjelinama 3.2 i 3.3 - odvojeno prikazujemo podatke za najsretnije zemlje svijeta (slika 5 - 45 zemalja sa vrijednošću indeksa iznad 6), najmanje sretne zemlje svijeta (slika 6-39 zemalja sa indeksom ispod 4.5) i za europske zemlje (slika 7). Podaci pokazuju da su najsretniji ljudi u Norveškoj (ocjena 7.5) dok skor od 7 i više još imaju i Danska, Island, Švicarska, Finska, Nizozemska, Kanada, Novi Zeland, Australija, Švedska, Izrael i Kostarika i Austrija. Većina najnesretnijih zemalja su u Africi, a na samom začelju su Tanzanija, Burundi i Srednjoafrička Republika. Hrvatska sa vrijednosti indeksa od 5.3 se nalazi na 77. mjestu i spada u manje sretne europske zemlje. Unutar članica EU nesretnije od nje su jedino Grčka, Portugal i Bugarska. Proširi li se opseg na ostale europske zemlje, tada su nesretniji još samo Kosovo, Crna gora, Bosna i Hercegovina, Makedonija, Albanija i Ukrajina.

Slika 9.

45 NAJSRETNIJIH ZEMALJA NA SVIJETU PREMA IZVJEŠĆU O SREĆI U SVIJETU ZA 2017. GODINU (PROSJEČNA OCJENA ZA RAZDOBLJE 2014. - 2016.)

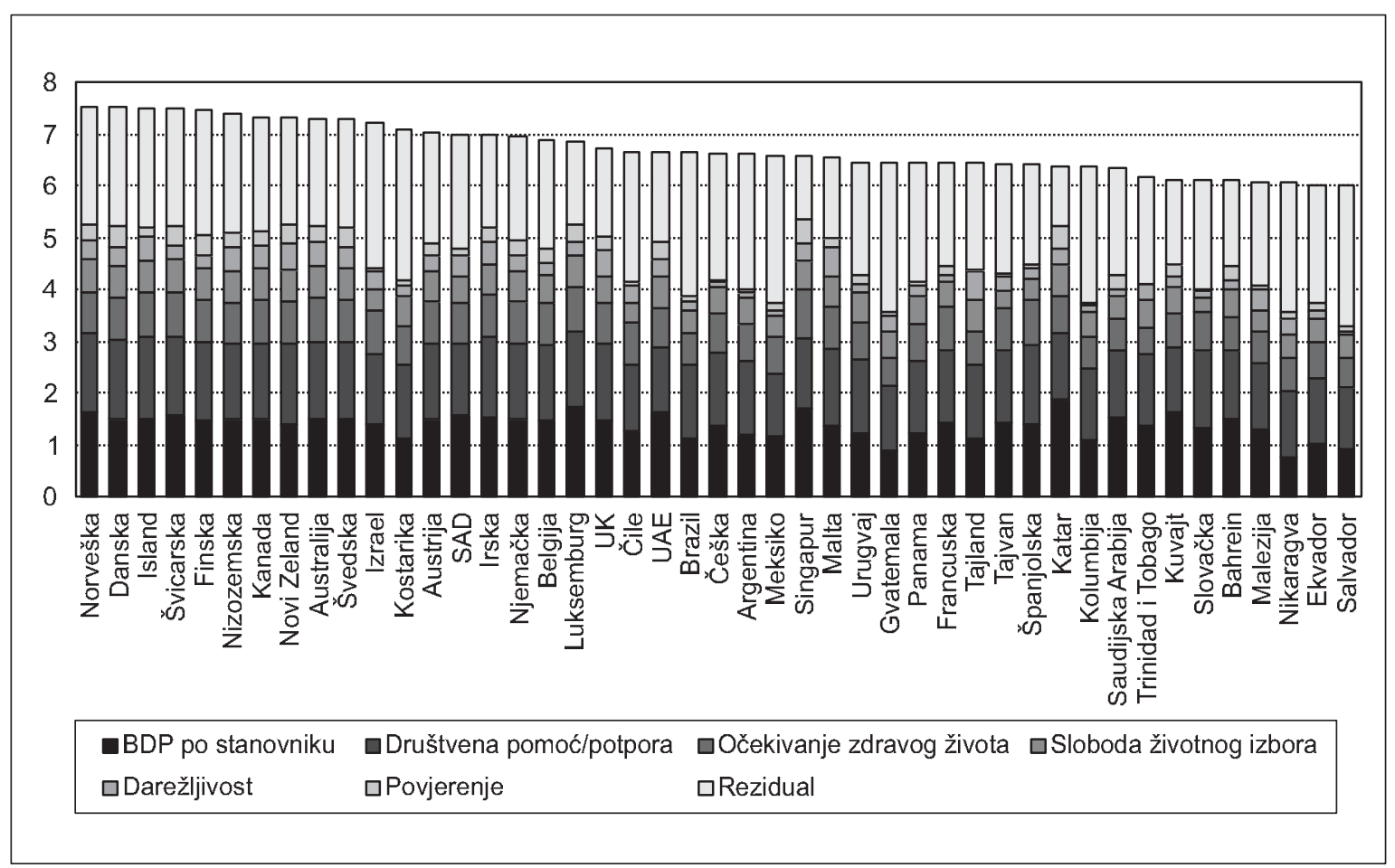

Izvor: Helliwell, Layard i Sachs (ur.), $2016 .$.

19 Metodologiju konstrukcije indeksa je moguće naći u Helliwell, Layard i Sachs(ur.) (2016.). 
Slika 10.

39 NAJMANJE SRETNIH ZEMALJA NA SVIJETU PREMA IZVJEŠĆU

O SREĆI U SVIJETU ZA 2017. GODINU (PROSJEČNA OCJENA ZA

RAZDOBLJE 2014. - 2016.)

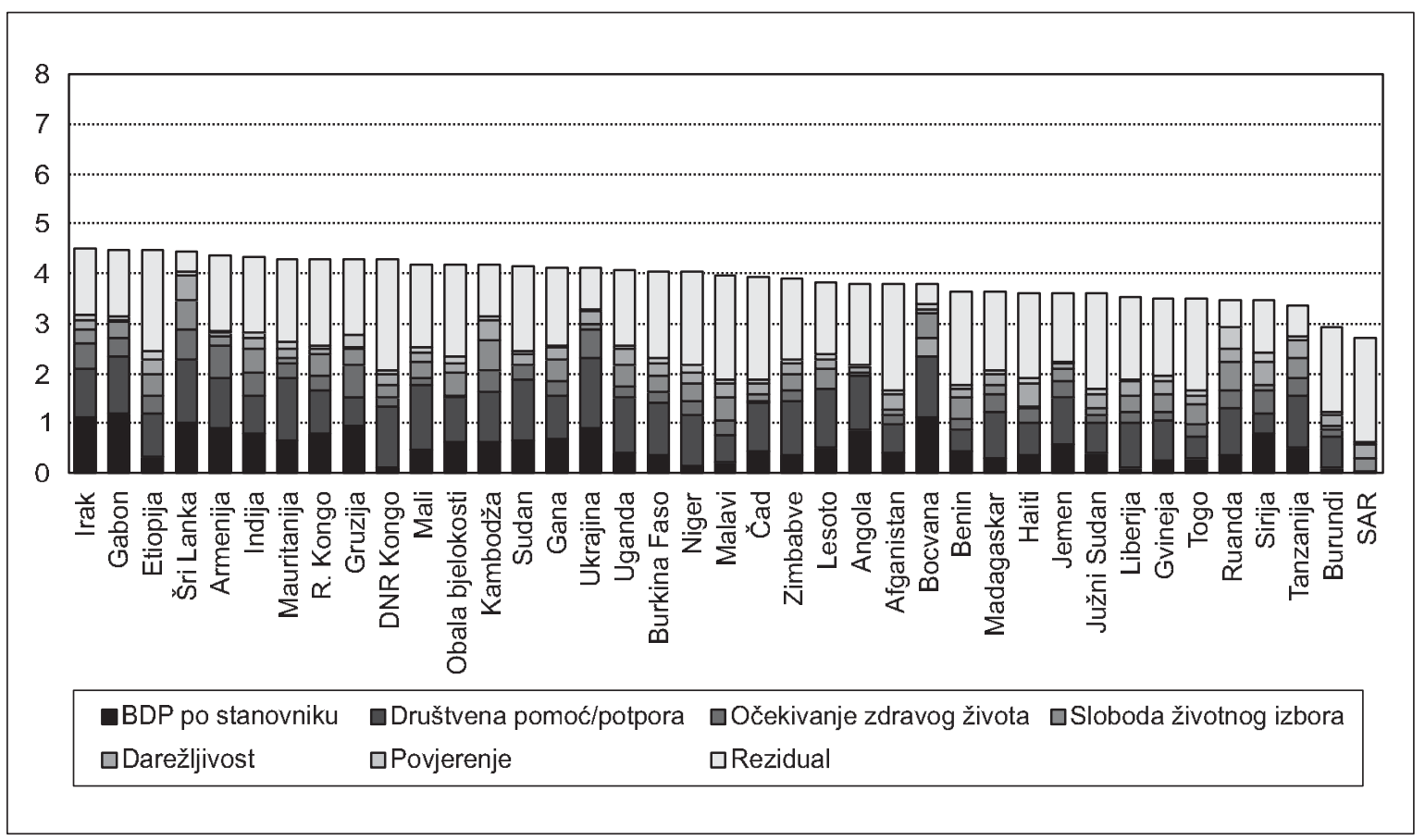

Izvor: Helliwell, Layard i Sachs (ur.) (2016.) 
Slika 11 .

EUROPSKE ZEMLJE PREMA IZVJEŠĆU O SREĆI U SVIJETU ZA 2017. GODINU (PROSJEČNA OCJENA ZA RAZDOBLJE 2014. - 2016.)

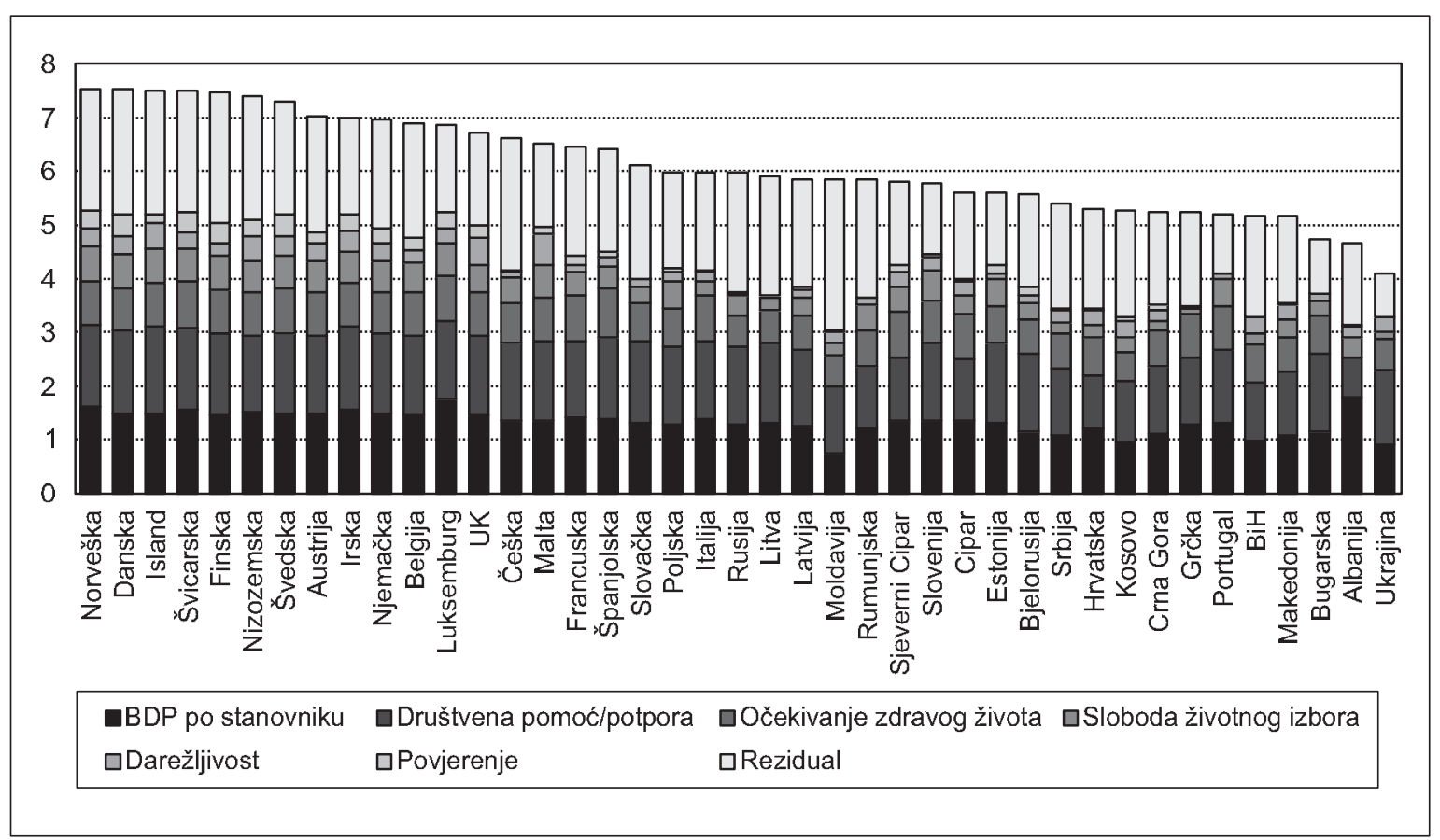

NAPOMENA: Podaci uključuju i Sjeverni Cipar.

Izvor: Helliwell, Layard i Sachs(ur.) (2016.)

Prezentirani indeks predstavlja zbroj podindeksa iz slijedećih sastavnica: BDP-a po stanovniku, Društvene pomoći, Očekivanja zdravog života, Slobode izbora, Darežljivosti i Povjerenja te rezidualne komponente. U svim prikazanim zemljama sreći najviše pridonose BDP po stanovniku i Društvena pomoć. Moguće je promatrati vrijednosti podindeksa i rangove za svaku od ovih zemalja, ali ce se, kao i u cjelini 3.3, na slici 12 prikazati samo rangovi Hrvatske. Na temelju slike može se zaključiti da Hrvatska natprosječni rezultat (rang manji od ranga prema ukupnom WHI-u) ima u komponentama: GDP po stanovniku, Očekivanje zdravog života te Darežljivost, ali pogoršanju ukupnog ranga pridonose Društvena pomoć, Sloboda na životne izbore i Povjerenje. 
Slika 12.

RANGOVI HRVATSKE PREMA KOMPONENTAMA WHI INDEKSA (PROSJEČNA OCJENA ZA RAZDOBLJE 2014. - 2016.)

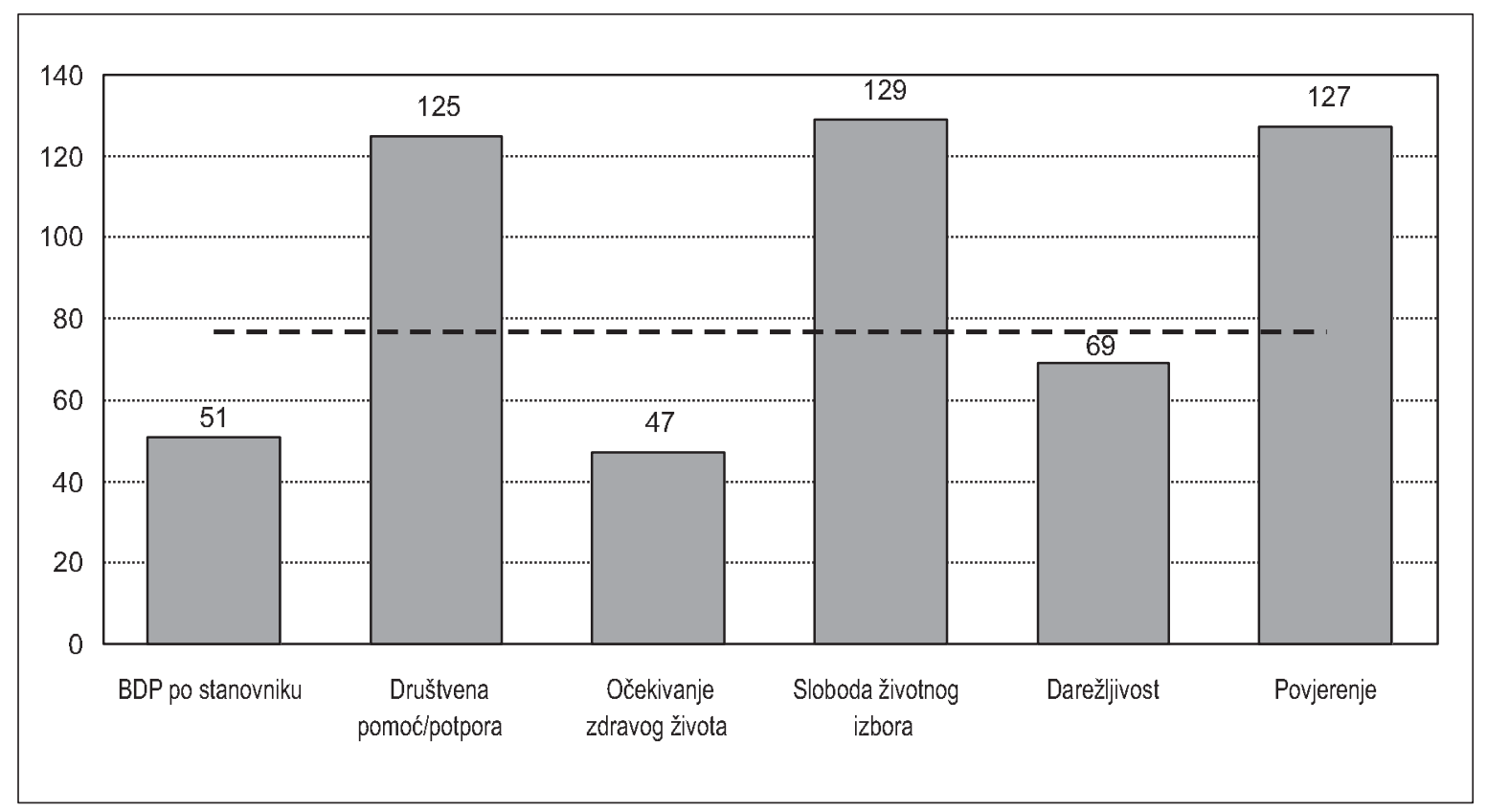

NAPOMENA: Isprekidana linija označava ukupan rang (77.)

Izvor: Helliwell, Layard i Sachs (ur.) (2016.).

\subsection{Kvaliteta života u Hrvatskoj}

Nekoliko projekata i indikatora omogućuju praćenje kvalitete života u Hrvatskoj, a među njima ćemo posebno obuhvatiti Hendalov indeks optimizma (HIO) i Nacionalni indeks sreće (NIS) ${ }^{20}$.

${ }^{20}$ Među projektima možemo spomenuti Razvoj nacionalnih indikatora kvalitete življenja iz 2003. g. pod vodstvom Instituta za društvena istraživanja „Ivo Pilar“ te Nacionalni indeks sreće koji je započeo 2010. godine a nastao je suradnjom časopisa Banka, Instituta za društvena istraživanja Ivo Pilar te agencije Hendal. Iz ovog drugog projekta je razvijen indeks NIS o kojem će više riječi biti u nastavku teksta. No postoje i drugi indikatori zadovoljstva, pa je tako npr. Hendal razvio i indekse poslovnog optimizma (HLIPO - razvijen u suradnji Hendala i poslovnog tjednika Lider) i indekse zadovoljstva trgovačkim lancima (IZTL indeks), ali oni nisu predmet proučavanja ovog rada. 


\subsubsection{Hendalov indeks optimizma}

Agencija Hendal prati HIO indeks od ožujka 2002. godine. Sam indeks predstavlja prosječnu vrijednost šest indeksa: Trenutnog zadovoljstva općim kretanjem gospodarskih prilika u Hrvatskoj, Trenutnog zadovoljstva osobnom kvalitetom života, Prognoze kako će se osobna kvaliteta života mijenjati u idućih šest mjeseci, Prognoze kretanja gospodarskih prilika u Hrvatskoj $u$ iducih šest mjeseci, Zadovoljstva osobnom kvalitetom života u proteklih šest mjeseci, te Predviđanja kako će se osobne financijske prilike mijenjati u idućih šest mjeseci. Sam indeks je važan pokazatelj ukupnog društvenog stanja i može biti od velike koristi u donošenju poslovnih odluka. Hendal ga konstruira prateći rezultate telefonskih intervjua na nacionalno reprezentativnom uzorku od 400 građana Hrvatske starijih od 15 godina ${ }^{21}$.

Slika 13.

\section{KRETANJE HIO INDEKSA PO MJESECIMA OD OŽUJKA 2002. DO VELJAČE 2016. G.}

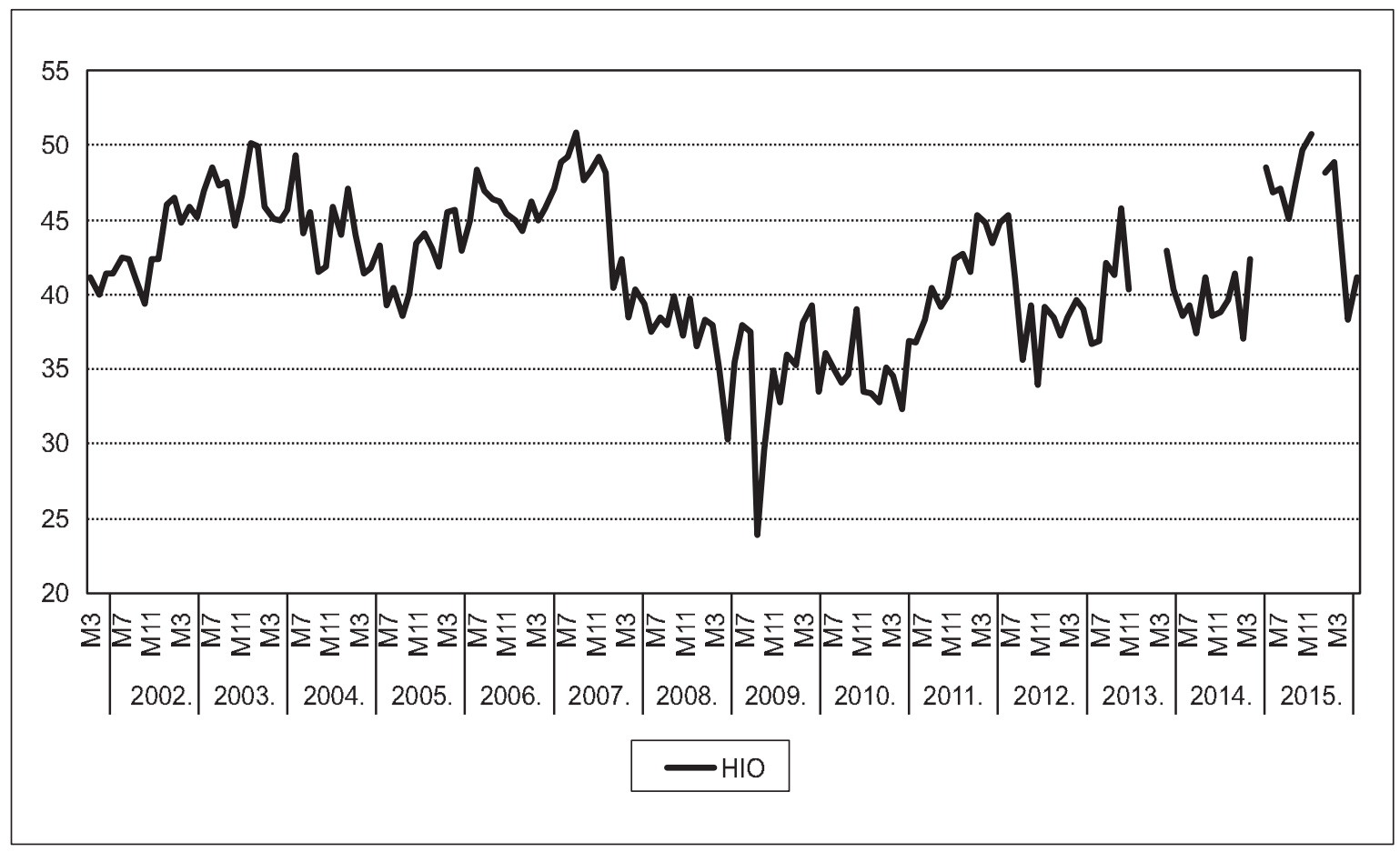

Izvor: Hendalov indeks optimizma, razna izdanja (dostupno na: www.hendal.hr)

${ }^{21}$ Prvi odlomak u cjelini 3.6.1. je načinjen uz pomoć: Hendalov indeks optimizma, razna izdanja (dostupno na: www.hendal.hr). 
Podaci o Hendalovu indeksu koji su predočeni na slici 13 pokazuju da se njegove vrijednosti uglavnom kreću između 35 i 50 . Budući da su ekstremni slučajevi ovog indeksa postavljeni na 0 (,totalni pesimist“) i 100 (,totalni optimist“), prema ovim rezultatima Hrvate bi se više moglo svrstati negdje između ,umjerenih pesimista“ i ,srednjih optimista“. Kakogod ih zvali, i kretanje ovog indeksa potvrđuje sliku o Hrvatima kao manje sretnom europskom narodu koja je potvrđena i ranijim pokazateljima.

Unatoč relativno stabilnom kretanju samog indeksa, izdvajaju se razdoblja rasta i smanjenja optimizma. Tako su u predkriznom razdoblju najveće vrijednosti indeksa zabilježene u prosincu 2003 (50.1) te srpnju 2007 (50.9) a najmanja u kolovozu 2005. (38.6). Prosječna vrijednost cijelog indeksa do srpnja 2007. iznosi 44.6. Snažniji pad indeksa se dogodio već u prosincu 2007. (40.1) i nastavio padati do veljače 2011 (32.3) sa najsnažnijim padom u ožujku (30.3) i srpnju 2009. g. (23.9). Prosječna vrijednost je indeksa nakon srpnja 2007. do veljače 2011. bila 37.15. Nakon veljače 2011., gdje postoji pristup podacima, uglavnom postoji tendencija rasta indeksa uz snažan pad u lipnju-kolovozu 2012. (33.9) te nakon ljeta 2015. g. Javno dostupna Hendalova serija prestaje sa veljačom 2016. g. pa nije moguće znati da li je porast indeksa između siječnja i veljače 2016. znak oporavka optimizma ili je privremenog karaktera.

Dostupni podaci na web stranici Hendala također omogućuju i praćenje indeksa po komponentama od prosinca 2010. do veljače 2016. g. Na slici 14 (desna) os posebno su izdvojena najlošija (Indeks zadovoljstva općim gospodarskim prilikama) i najbolja komponenta (Indeks optimističnosti za kvalitetu življenja u slijedećih šest mjeseci) HIO. Stupci na slici 14 odvojeno promatraju razlike Indeksa optimističnosti za gospodarske prilike otprije šest mjeseci i Indeksa optimističnosti za gospodarske prilike u trenutnom mjesecu, Indeksa kretanja kvalitete života u zadnjih šest mjeseci i Indeksa zadovoljstva trenutnom kvalitetom života te Indeksa optimističnosti za kvalitetu življenja otprije šest mjeseci i Indeksa zadovoljstva trenutnom kvalitetom života. Pozitivne prva i treća razlika pokazuju da su prije šest mjeseci očekivanja ljudi glede trenutne gospodarske situacije / kvalitete života bila znatno bolja u odnosu na ostvarenje. U slučaju druge razlike pozitivan predznak podrazumijeva da ljudi znatno, ,pozitivnije“ doživljavaju kvalitetu života tijekom zadnjih mjeseci u odnosu na trenutnu situaciju. Uočava se i da su razlike više izražene kad se promatra zadovoljstvo općim gospodarskim prilikama nego u slučaju kvalitete života što navodi na mogućnost da su ljudi realističniji u procjeni kvalitete života nego u procjeni gospodarskih kretanja. 
Slika 14.

\section{RAZLIKA IZMEĐU OČEKIVANJA ZA ŠEST MJESECI I OCJENE TRENUTNE SITUACIJE PREMA HIO}

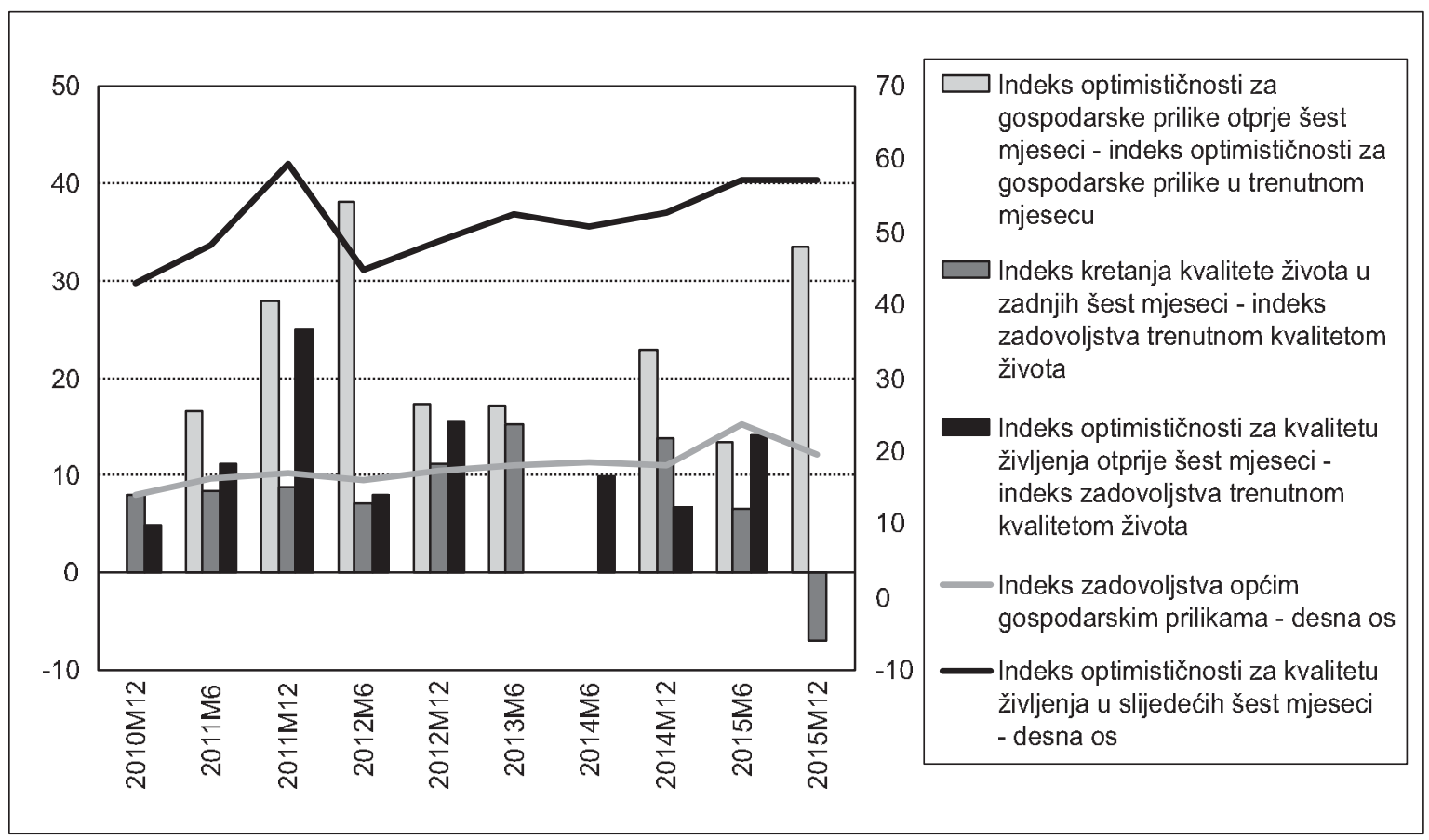

NAPOMENA: Izostaju neki podaci za prosinac 2010., lipanj 2013., prosinac 2013., lipanj 2014. i prosinac 2015. zbog nedostatka podataka na web stranici agencije Hendal.

Izvor: Izračun autora na temelju: Hendalov indeks optimizma, razna izdanja (dostupno na: www. hendal.hr).

\subsubsection{Nacionalni indeks sreće (NIS)}

Detaljniji pokušaj praćenja sreće u Hrvatskoj u odnosu na HIO je bio tzv. Nacionalni indeks sreće (NIS). Riječ je o istraživanju časopisa Banka i agencije Hendal koje se provodi od početka 2010. g. Izvješća o samom indeksu dostupna na web stranici Hendala omogućuju praćenje indeksa od veljače 2010. do srpnja 2012. g. Njime se procjenjuje razina sreće/dobrobiti/kvalitete života u populaciji (uzorkovanje se provodi nad građanima RH koji su stariji od 15 godina, a telefonska anketa se provodi na 750 ispitanika). Vrijednosti mu se kreću od 0 do 100 bodova pri čemu je 0 najgora, 100 najbolja a 50 srednja vrijednost po pitanju srece/dobrobiti/kvalitete života. Shodno navedenom sve vrijednosti ispod 50 bodova možemo okarakterizirati kao „nesreću“, a sve iznad te razine kao „sreću“. Budući 
da građani kroz devet komponenti ocjenjuju kvalitetu života u Hrvatskoj, indeks se računa kao prosječna vrijednost komponenti koje ga sačinjavanju pa je indeks kompozitna mjera koja reflektira razinu zadovoljstva pojedinim aspektima života (Došen i Ralašić, 2010.).

Komponente Nacionalnog indeksa sreće su slijedeće: Opće zadovoljstvo životnom situacijom, Procjena općeg zadovoljstva životnom situacijom za 2 godine, Emotivno stanje na osnovu doživljenih emocija, Zdravo ponašanje, Uvjeti u radnoj (školskoj) okolini, Zdravstveno stanje, Osnovni uvjeti za život, Odnos prema okolišu te Zadovoljstvo osobnim razvojem i socijalnom okolinom. Ovih 9 komponenti zahvaćaju područja koja nam govore o kvaliteti života u Hrvatskoj, ali i o subjektivnom osjećaju zadovoljstva pojedinim aspektima života. Što one prate, predočeno je u tablici 5 u Dodacima. Naravno, premda se temelje na odgovorima ispitanika, ove se komponente NIS-a razlikuju međusobno po načinu mjerenja, ali su sve mjerene na kvantificiranim skalama i matematički svedene na skalu od 0 do 100 kako bi bile međusobno usporedive te komparabilne i sa samim NIS-om .

Slika 15.

\section{VRIJEDNOSTI NIS-A I NJEGOVIH KOMPONENTI U VELJAČI 2010. GODINE}

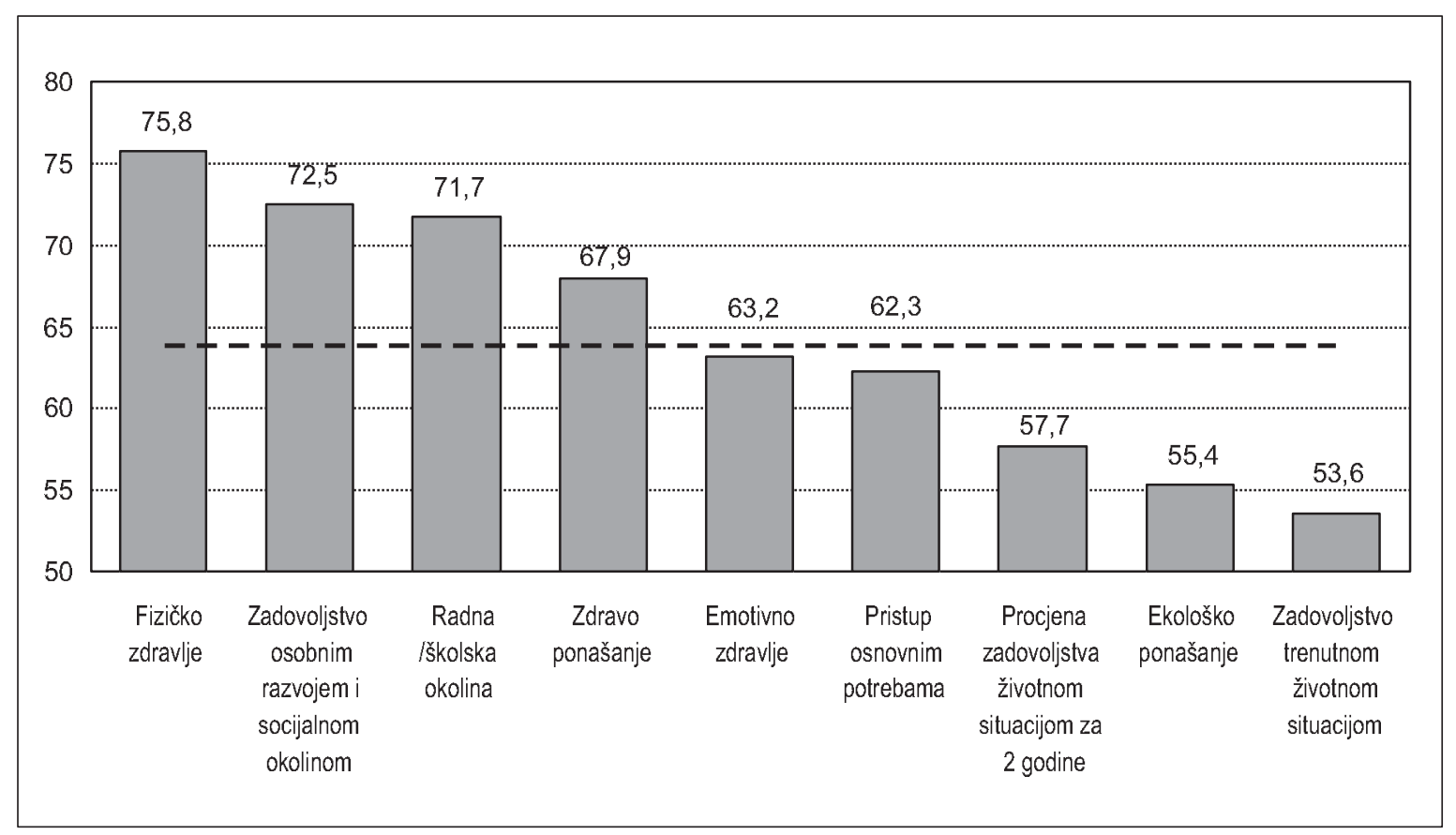

NAPOMENA: Isprekidana linija odražava opću razinu NIS-a u veljači 2010. g. (63.8).

Izvor: Došen i Ralašić (2010.) 
Početna razina NIS-a (veljača 2010.) na slici 15 je veća od 50, što ukazuje na relativno sretnu populaciju ${ }^{22}$. U sklopu indeksa se posebno izdvajaju komponente čiji su podindeksi veći od samog NIS-a. Shodno tome, možemo zaključiti da Fizičko zdravlje, Zadovoljstvo osobnim razvojem i socijalnom okolinom, Radna (školska) okolina i Zdravo ponašanje podižu opću razinu NIS-a. Među komponentama koje smanjuju razinu NIS-a svakako treba spomenuti: Zadovoljstvo trenutnom životnom situacijom, Ekološko ponašanje te Procjenu zadovoljstva životnom situacijom za dvije godine jer su vrijednosti njihovog indeksa znatno ispod opće razine NIS-a. Blizu te razine (ali ipak ispod nje) su podindeksi za Emotivno zdravlje i Pristup osnovnim potrebama.

Slika 16.

\section{TREND NIS-A OD PRVOG KVARTALA 2010. DO TREĆEG KVARTALA 2013. GODINE}

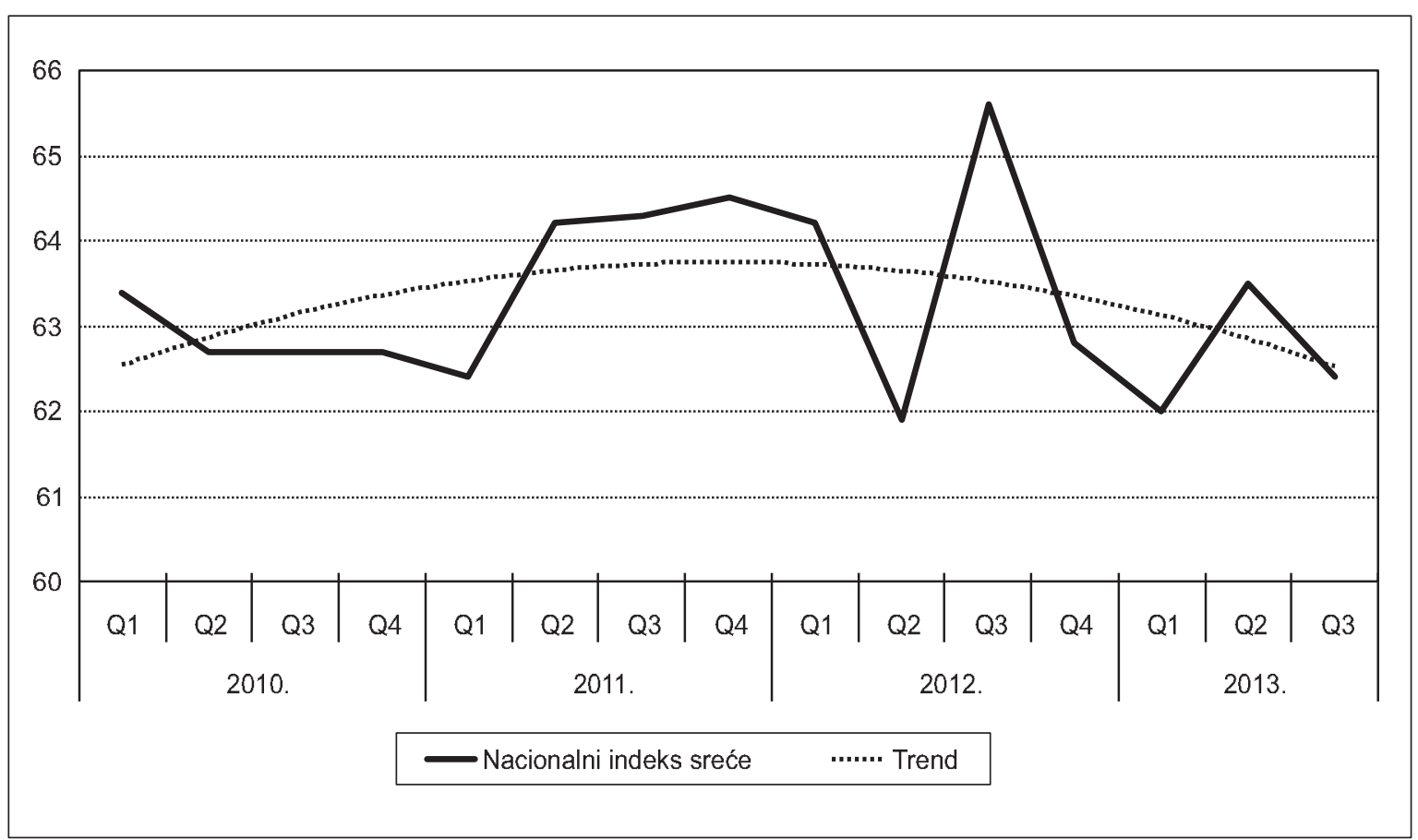

Izvor: Hajdari (2013.b)

Premda slika 16 upućuje na blago poboljšanje NIS-a tijekom 2011. te blago pogoršanje u tijekom 2012. i 2013. g.), analiza može biti i detaljnija. Slika 17

${ }^{22}$ Valja paziti pri interpretaciji indeksa jer početna vrijednost indeksa od 63.8 ne podrazumijeva da je $63.8 \%$ ljudi zadovoljno svojom životnom situacijom. 
prati kretanje NIS-a i njegovih komponenti do drugog kvartala 2012. Tu se uočava da znatno veće vrijednosti od NIS-a imaju: Zdravlje, Radna (školska) okolina, Zadovoljstvo osobnim razvojem i socijalnom okolinom i Zdravo ponašanje. Slabije vrijednosti od NIS-a imaju: Pristup osnovnim potrebama i Procjena zadovoljstva životnom situacijom za dvije godine, a naročito to vrijedi za Zadovoljstvo trenutnom životnom situacijom i Ekološko ponašanje.

\section{Slika 17.}

\section{KRETANJE NIS-A I NJEGOVIH KOMPONENTI OD PRVOG KVARTALA 2010. DO DRUGOG KVARTALA 2012. G.}

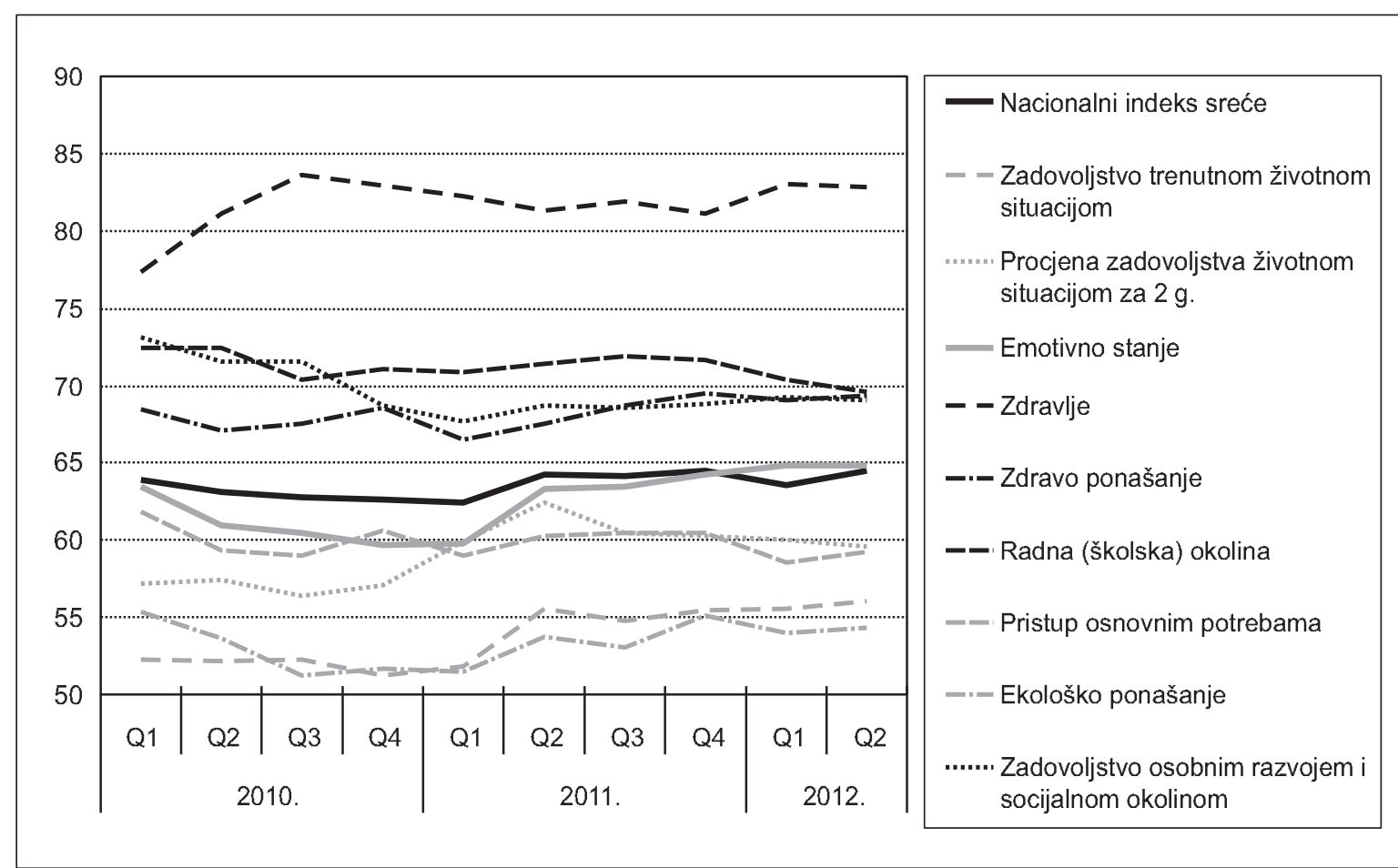

NAPOMENA: podaci na web stranici Hendala omogućuju praćenje NIS-a do drugog kvartala 2012. g. Izvor: Načinjeno na temelju: Nacionalni indeks sreće, razna izdanja (dostupno na: www.hendal.hr).

Već ovakva „razdvojenost“ komponenti NIS-a, a imajući u vidu da gotovo svaka sadrži pet do deset vlastitih sastavnica, navodi na zaključak da postoje neke subkomponente NIS-a sa jako visokom i sa jako niskom vrijednošću. Sa svim subkomponentama koje se tiču zdravlja Hrvati su većinom jako zadovoljni. Rezultate kod preostalih komponenti je moguće sažeti u slijedećih nekoliko zaključaka ${ }^{23}$ :

${ }^{23}$ Preuzeto iz Došen i Ralašić (2010.) za veljaču 2010., ali se zaključci neće značajnije mijenjati ni u kasnijim razdobljima. Analiza se dodatno može praviti i s obzirom na karakteristike 
1. Iako je značajno zadovoljstvo osobnim razvojem i socijalnom okolinom, Hrvati su najviše zadovoljni odnosima s bliskim ljudima (obitelj, prijatelji), a najmanje državom;

2. Zaposleni građani u situaciji visoke nezaposlenosti su prilično zadovoljni poslom i uvjetima na poslu iako je najlošije ocijenjeno iskorištavanje vlastitih potencijala unutar radne/školske okoline. Prema istraživanjima NIS-a zadovoljstvo poslom može se objasniti činjenicom da u uvjetima visoke zaposlenosti imaju posao (Galić, 2010., Hajdari, 2013.a). Na to upućuje i činjenica da su zaposlenici često nezadovoljni načinom kako se poslodavac odnosi prema njima (Hajdari, 2013.a) te da su Hrvati nakon 55. godine života sve nesretniji jer je veliki broj ljudi u punoj radnoj snazi otišao u mirovinu (Vehovec, 2011.);

3. Nasuprot uvriježenom stavu da se nezdravo hrane Hrvati redovito konzumiraju svježe voće i povrće. No, konzumacija brze i teške hrane čini se većim problemom od pušenja i alkohola.

Detaljnija se analiza može provesti i za komponente sa nižim ili sličnim razinama kao i NIS pa se uočava (Došen i Ralašić, 2010.):

1. Hrvati su najnezadovoljniji trenutačnom životnom situacijom, ali i budućnošću, što znači da nisu jako optimistični ${ }^{24}$.

2. Ekološko se ponašanje razlikuje ovisno o subkomponenti koja se promatra pa su tako ljudi aktivni oko štednje vode i odvajanja PVC-a ili staklenog otpada, ali je upotreba javnog prijevoza i razdvajanje organskog otpada na jako niskoj razini.

3. Osnovne potrebe imaju nešto manju vrijednost indeksa od ukupnog NIS-a ali tome pridonosi nedostatak sredstava za hranu, stanovanje, odjeću i obuću i „male luksuze“25. Dostupnost i kvalitetu pitke vode te zadovoljstvo susjedstvom građani ocjenjuju većim indeksom u odnosu na ukupan NIS.

ispitanika poput dobi, spola, regionalne pripadnosti, obrazovanja i sl., ali glede toga upućujemo čitatelja na izvješća o NIS-u dostupna na web stranici agencije Hendal (www.hendal.hr) i izdanja časopisa Banke od travnja 2010. nadalje.

${ }^{24}$ Do sada nismo pratili stavove ispitanika prema dobi ili spolu ovdje ističemo da je najveće zadovoljstvo trenutnom i situacijom za dvije godine kod skupine između 15. i 24. godine starosti, ali barem malo poboljšanje očekuje i populacija stara između 25 i 34 godine dok najstariji dio radnog kontingenta (55. - 64. g.) imaju najniže procjene kako sadašnje tako i buduće situacije. Također stupanj optimizma u pogledu budućnosti je više izražen kod žena (Došen i Ralašić, 2010.).

${ }_{25}$ Ovdje također upozoravamo na razlike u krajevima Hrvatske. Tako je Zadovoljenje osnovnih potreba je na znatno višoj razini u zagrebačkoj regiji, te u Istri, Primorsko-goranskoj županiji i Dalmaciji nego u ostalim dijelovima RH. Ekološko ponašanje na najvišoj je razini u Zagrebu, sjevernoj Hrvatskoj, Istri Primorju i Gorskom kotaru, a na najnižoj u Dalmaciji (Došen i Ralašić, 2010.). 
4. Hrvati više doživljavaju pozitivne emocije kao što su ljubav, sreća ili užitak negoli zabrinutost, tugu ili stres. Ipak, emotivno stanje slabi sa starenjem jer su starije osobe emotivno najslabije, a pozitivne su emocije najjače kod mlađe populacije (od 15. do 24. g.).

NIS se također može uspoređivati i sa drugim indeksima pa je na slici 18 predočena usporedba za veljaču 2010. sa Indeksom blagostanja (engl. Wellbeing index) koji izdaje institut Gallup za SAD. Slika pokazuje neznatno lošiji rezultat u odnosu na SAD. Rezultati u korist Hrvatske su u radnoj (školskoj) okolini, zdravom ponašanju i zadovoljstvu trenutnom ili očekivanom zadovoljstvu za dvije godine. SAD je znatno bolji u emotivnom zdravlju i pristupu osnovnim potrebama. Najveća se razlika odnosi na radnu okolinu jer se mjerila u veljači 2010. na zaposlenima pri stopi nezaposlenosti od 9.7\% u SAD-u nasuprot 17.7\% u Hrvatskoj (Došen i Ralašić, 2010., str. 32).

Slika 18.

\section{USPOREDBA NIS-A I INDEKSA GALLUPOVOG INSTITUTA U SAD-U (VELJAČA 2010.)}

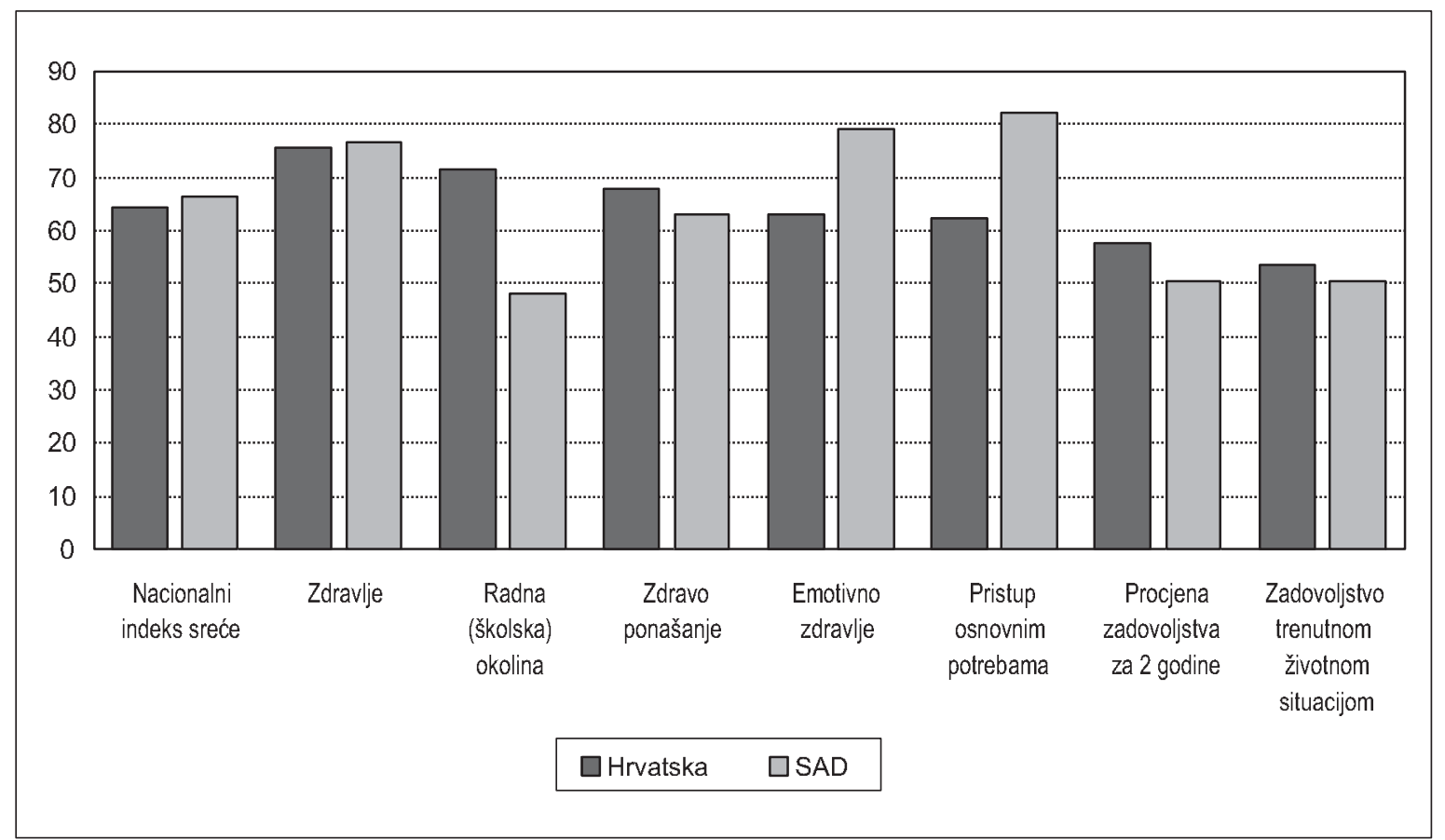

NAPOMENA: U usporedbi sa slikom 15 vrijednost NIS-a je korigirana tako da maksimalno bude usporediv sa Indeksom blagostanja Gallupa.

Izvor: Došen i Ralašić (2010., str. 32). 
Interpretacijska vrijednost indeksa ne proizlazi samo iz njegove apsolutne razine, već i njegove dinamike pa kontinuirano praćenje indeksa omogućava uočavanje, ali i anticipiranje promjena. Primjerice, prethodno objašnjeni HIO indeks je ukazivao na rast pesimizma i prije izbivanja recentne krize. Ma koliko god ukupan NIS tijekom 2012. i 2013. imao trend blagog smanjenja, nužno je istaknuti da se situacija najviše pogoršavala u komponenti Procjena zadovoljstva u slijedeće dvije godine (slika 17 i Hajdari, 2013.b) pa su vrijednosti ovog podindeksa tijekom 2013. g. i za 4-5 indeksnih bodova manje u odnosu na prvi kvartal 2010. g. što je najbolji pokazatelj koliko se kriza popraćena snažnom nezaposlenošću odrazila na sreću stanovništva ${ }^{26}$. Paralelno sa ovim podindeksom treba istaknuti i Pristup osnovnim potrebama koji također ima ispodprosječne vrijednosti u odnosu na ukupan NIS. Narušavanje standarda pokazuju i podaci DZS-a da oko trećine hrvatskog stanovništva živi ispod praga siromaštva što ne stvara podlogu za optimizam. Nizak prostor za optimizam pokazuje rast zabrinutosti i ljutnje u Hrvata (Hajdari, 2014.). Međutim, od „pozitivnih“ podkomponenti NIS-a valja istaknuti podindeks Zadovoljstva osobnim razvojem i socijalnom okolinom koji, iako se u recentnoj krizi smanjio za oko 3-4 boda, i dalje ima natprosječno visoku vrijednost. Na njegovu visoku vrijednost osobito utječu komponente Zadovoljstvo sa bliskim ljudima (obitelj, prijatelji) koja i u krizi premašuje 80, te Zadovoljstvo osobnim duhovnim razvojem i Zadovoljstvo mjestom, selom, gradom u kom živite (većinom natprosječne vrijednosti u odnosu na podkomponentu Zadovoljstvo osobnim razvojem $i$ socijalnom okolinom) dok je, nasuprot njima, prisutno nezadovoljstvo državom (Ralašić, 2012.b) ${ }^{27}$.

NIS je bio mjerljiv, objektivan i brojčani pokazatelj za praćenje kvalitete življenja u Hrvatskoj i djelotvornosti društva u zadovoljavanju potreba i očekivanja ljudi. Za razdoblje koje pokriva (2010. - 2014.) njegovi mikropodaci su korisni za ekonomsku analizu, ali i brojne druge struke poput sociologije, politologije i psihologije (Bićanić, 2010.). Osobito su važne koristi ovog indeksa u psihologiji gdje se sve više ističe važnost pozitivnih emocija jer bolje razmišljamo kada smo sretni, produktivnost nam je viša, a poboljšavaju se i međuljudski odnosi. Indeks je također bio koristan i za nositelje ekonomske politike i općenito nositelje vlasti jer nam nameće pitanje kako poboljšati sreću Hrvata u onim komponentama gdje njihovi podindeksi poprimaju relativno niske odnosno ispodprosječne vrijednosti.

${ }^{26}$ Tijekom 2010. g. podindeks procjene zadovoljstva životnom situacijom za dvije godine se kretao na 56-57 bodova. 2011. g. je bila optimističnija sa porastom indeksa do 62 boda u prvoj polovici godine. U drugoj polovici te godine dolazi do smanjivanja ovog podindeksa koje se uz povremeno povećanje nastavlja tijekom 2012. i 2013. godine.

${ }^{27}$ Detaljnije je o komponentama NIS-a moguće naći u brojevima Banke od travnja 2010. do prosinca 2014. g. 


\section{Pokazatelji sreće i ekonomska aktivnost}

U dosadašnjem dijelu teksta pratili su se pokazatelji sreće i u cjelini 3 je pokazano da su najuspješnije i najsretnije zemlje najčešće one koje imaju visok dohodak. Polazeći od ekonomske teorije, zaista je moguće očekivati da zemlje koje ostvaruju veći dohodak imaju i sretnije stanovništvo. To je vrlo jednostavno objasniti jer u tim zemljama, osim što su bogatiji, ljudi rade mnogo manje i imaju dulji godišnji odmor što im omogućuje više dokolice ali su i zdraviji što im omogućuje i duži život. Odnos se, međutim, može postaviti i u suprotnom smjeru jer su sretniji i zadovoljniji ljudi mnogo produktivniji što onda pridonosi i većem dohotku ${ }^{28}$.

Poveznicu između sreće i ekonomske aktivnosti ćemo pokušati uspostaviti preko jednostavne analize. Indikator sreće će biti indeks sreće sveučilišta Erasmus koji je već obrađen u poglavlju 3.2. (varijabla ROTTER). Ekonomsku aktivnost će pratiti pokazatelji poput BDP-a po stanovniku (varijabla AVG_GDPPC), BDP-a po stanovniku prema PPP u međunarodnim dolarima iz 2011. godine (varijabla $\mathrm{AVG}_{-}$ GDPPCPPP), te stope rasta BDP-a (varijabla AVG_GROWTH) - podaci preuzeti iz baze World Development Indicators (WDI). Budući da podaci Erasmusa prate prosječnu vrijednost indeksa sreće za razdoblje 2005. - 2014., iz WDI-a su također uzete zemlje koje imaju podatke o ekonomskoj aktivnosti u istom razdoblju. Zbog toga je analiza obuhvatila 152 zemlje svijeta koje su ovisno o veličini svojeg dohotka razvrstane u skupinu sa visokim, višim srednjim, nižim srednjim i niskim dohotkom kako to čini i Svjetska banka.

Tablica 2.

PROSJEČNE VRIJEDNOSTI ODABRANIH VARIJABLI ZA RAZDOBLJE 2005. - 2014. G. ZA ODABRANE SKUPOVE ZEMALJA

\begin{tabular}{|l|c|c|c|c|c|c|}
\hline & & & \multicolumn{2}{|c|}{ Apsolutne veličine } & \multicolumn{2}{c|}{ Logaritmirane veličine } \\
\hline Zemlja & ROTTER & $\begin{array}{c}\text { AVG_ }_{-} \\
\text {GROWTH }\end{array}$ & $\begin{array}{c}\text { AVG_ } \\
\text { GDPPC }\end{array}$ & $\begin{array}{c}\text { AVG_GDP- } \\
\text { PCPPP }\end{array}$ & $\begin{array}{c}\text { AVG_- }_{\text {GDPPC }} \\
\text { AVG_GDP- } \\
\text { PCPPP }\end{array}$ \\
\hline Sve & 5.899 & 4.079 & 13378.257 & 17408.188 & 8.462 & 9.116 \\
\hline Visok dohodak & 7.016 & 2.193 & 37086.139 & 41356.731 & 10.368 & 10.538 \\
\hline Viši srednji dohodak & 6.185 & 4.293 & 6700.222 & 13451.280 & 8.745 & 9.460 \\
\hline Niži srednji dohodak & 5.471 & 5.307 & 1974.317 & 5073.273 & 7.471 & 8.435 \\
\hline Niski dohodak & 4.152 & 5.068 & 547.544 & 1354.519 & 6.244 & 7.154 \\
\hline
\end{tabular}

Izvor: Izrada autora na temelju podataka iz: Veenhoven (2015.a) i World Development Indicators

${ }^{28}$ Tako se može pokazati i da su kompanije sa sretnim zaposlenicima profitabilnije i atraktivnije investitorima pa je i stvaranje boljeg radnog okružja bitan čimbenik održivog i dugoročnog rasta (Ralašić, 2012.a). 
Već površan pogled na tablicu 2 cee pokazati da natprosječnu vrijednost indeksa sreće imaju zemlje sa visokim i višim srednjim dohotkom. Zemlje nižeg srednjeg dohotka su blago ispod prosjeka dok su najmanje sretne zemlje one koje imaju niski dohodak. Obrnuto proporcionalno kretanju indeksa sreće je bilo kretanje stopa rasta. Tako su ispodprosječan rast imale samo zemlje sa visokim dohotkom dok je u preostalim skupinama zemalja on bio natprosječan, a najveći je bio u zemljama nižeg srednjeg i niskog dohotka.

Stoga je opravdano postaviti pitanje povezanosti između ekonomske aktivnosti i sreće. Postojanje takve veze ćemo pokušati utvrditi jednostavnom regresijskom analizom predočenom u tablici 3. Ponavljamo kako se odnos između ekonomske aktivnosti i sreće može proučavati sa oba smjera pa je ovdje arbitrarno prosuđeno da zavisna varijabla bude BDP po stanovniku, a nezavisna indeks sreće ${ }^{29}$. Prema tome regresijska jednadžba poprima oblik:

$$
\text { LOGAVGGDPPC }_{i}=\alpha+\beta * \mathrm{ROTTER}_{i}+u_{i}
$$

pri čemu je BDP po stanovniku (koji će biti u međunarodnim dolarima i prema paritetu kupovne moći) logaritmiran, a $u_{i}$ predstavljaju reziduale. Rezultati prezentirani u tablici 3 pokazuju pozitivnu vezu između ovih varijabli kad su uključeni svi podaci. Međutim, kad se analiza vrši na kvartilima zemalja, tada je veza prisutna samo u kvartilu najbogatijih zemalja. Kod ostalih kvartila veza nije signifikantna pri čemu su izuzetak jedino zemlje nižeg srednjeg dohotka ukoliko je BDP izražen u paritetu kupovne moći. Tada je veza između BDP-a po stanovniku i indeksa sreće također pozitivna, ali slabije magnitude nego kod najbogatijih zemalja.

29 Jednostavna regresija koja prati prezentirane oblike dana je općenitim izrazom:

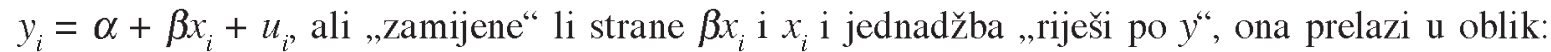
$x_{i}=-\frac{\alpha}{\beta}+\frac{1}{\beta} y_{i}+\frac{1}{\beta} u_{i}$. Stoga signifikantna $\beta$ u prvoj jednadžbi podrazumijeva i signifikantnu $1 / \beta$ u drugoj. 


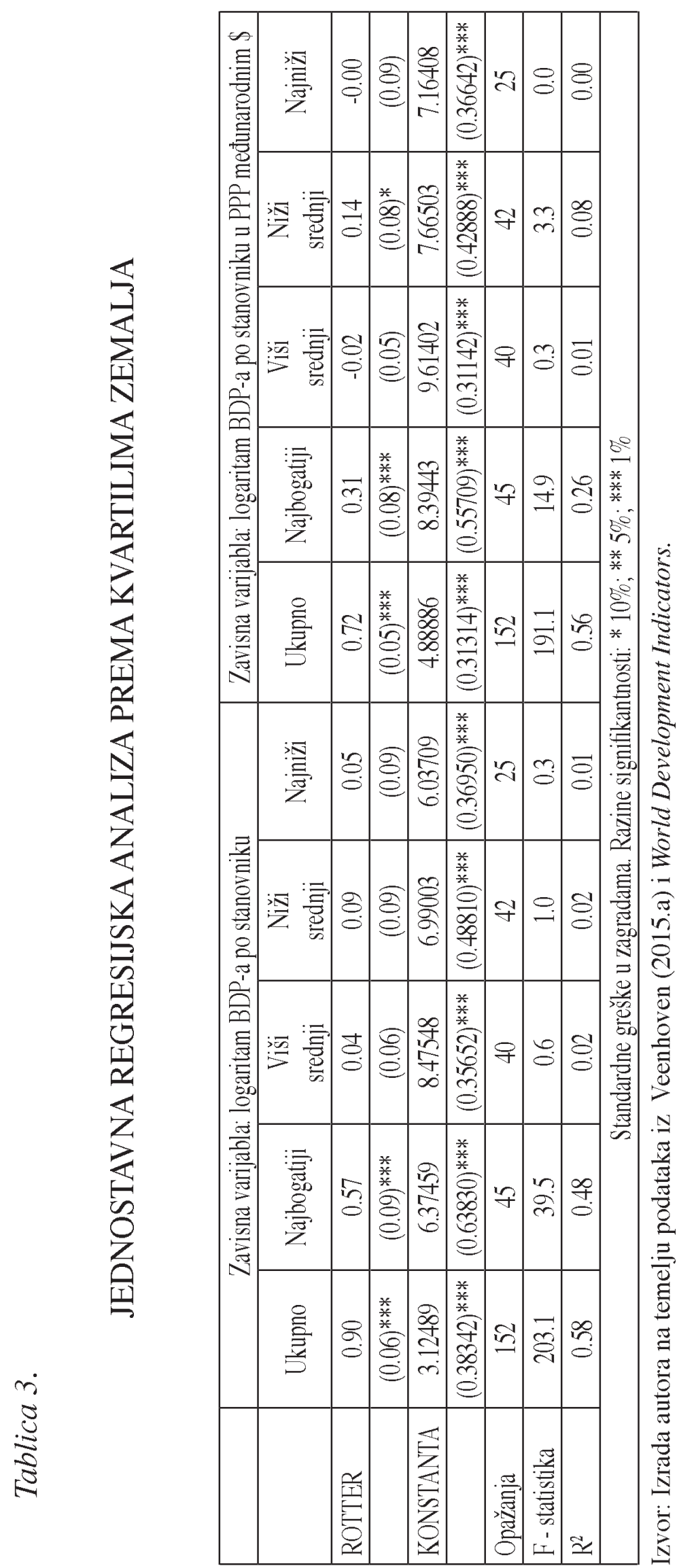


Dobiveni rezultati samo pokazuju signifikantnu korelaciju u skupini zemalja sa najvišim dohotkom, ali ništa ne govore o tome da li veća sreća dovodi do većeg dohotka ili veći dohodak uzrokuje veću sreću ${ }^{30}$. Prikazana pojednostavljena analiza nije u mogućnosti dati odgovor na takvo pitanje pa će se posegnuti rezultatima već objavljenih istraživanja.

Jedan od prvijenaca kojima se prati veza između dohotka i sreće stanovnika je (Easterlin, 1974.) gdje je pokazano da ljudska sreća ne raste kako zemlja postaje bogatija iako su u danoj jedinici vremena sretnije zemlje sa većim dohotkom. Sam rezultat je bio iznenađujući pa je među istraživačima poznat kao Easterlinov paradoks. Premda su razvijenije zemlje „u prosjeku“ sretnije od onih slabije razvijenih, iznenađujuće kod tog zaključka je to što ljudi na Zapadu nisu postali ništa sretniji premda su postali mnogo bogatiji i imaju više dokolice te dug i zdrav život. Objašnjenja ovog paradoksa su već dana u Easterlin (1995., 2001.) i (Clark, Frijters i Shields (2008.) i povezana su sa hipotezom relativnog bogatstva (osjećat cemo se sretniji i imati više pouzdanja ukoliko npr. imamo dva automobila, a ostali samo jedan, ali ne i ako se uspoređujemo sa onima koji voze luksuzniji automobil, ako i mi sami nemamo takav). Easterlinov paradoks je kroz zadnjih 15-ak godina pobudio interes istraživača. Tako, Frey i Stutzer (2002.a) ističu da u danoj jedinici vremena zemlje sa većim dohotkom jesu sretnije, ali se sreća u zemlji ne povećava kako zemlja postaje bogatija te daju primjer zapadnih zemalja i Japana gdje se sreća nije povećala iako je dohodak po stanovniku drastično porastao. Do sličnog zaključka dolaze Blanchflower i Oswald (2004.) na podacima za SAD i Veliku Britaniju. Oswald (1997.) ističe da osjećaj zadovoljstva raste sa rastom dohotka, ali je rast malen te ga ponekad nije moguće detektirati. Zato je moguće, po njemu, da politike koje potiču rast kod bogatih zemalja budu od slabe koristi kad se analizira sreća. Hagerty i Veenhoven (2003.) su utvrdili da Easterlinov paradoks uopće ne postoji odnosno da zemlja postaje sretnija kako joj dohodak raste. Sa njihovim zaključcima se slažu Stevenson i Wolfers (2008.) jer se porast apsolutnog dohotka pokazao u pozitivnoj vezi sa iskazanom srećom premda je povećanje sreće bilo sporije od povećanja dohotka. Na njihovom tragu je i Deaton (2008.) smatrajući da je zadovoljstvo životom veće u zemljama sa većim dohotkom i da nema dokaza da veza iščezava kako zemlja postaje bogatija. Ipak u isto vrijeme potvrđuje i negativnu vezu između zadovoljstva životom i gospodarskog rasta. Za razliku od njega Sacks, Stevenson i Wolfers (2010.) zaključuju da je veza između zadovoljstva životom i gospodarskog rasta pozitivna. Dodatno potvrđuju i da Easterlinov paradoks ne postoji odnosno da je veza između zadovoljstva životom i BDP-a po stanovniku pozitivna. Međutim, Easterlin i Angelescu (2009.)

${ }^{30}$ Izdanje Harvard Business Review za siječanj - veljaču 2012. g. je bilo posvećeno faktoru sreće - kako poboljšati vlastitu sreću i kako sreća potiče učinkovitost. 
Easterlin i dr. (2010.) i Easterlin (2016.) pokazuju da Easterlinov paradoks postoji u dugom roku u razvijenim zemljama, ali i u velikim broju zemalja u razvoju sreća ne raste sa rastom dohotka. Ipak, pozitivna veza se potvrđuje u kratkom roku pa autori odbacivanje Easterlinovog paradoksa pripisuju zbrci u razlikovanju kratkoročne i dugoročne veze. Da Easterlinov paradoks postoji u dugom roku također su pokazali i Di Tella, MacCulloch i Oswald (2003.), Di Tella i MacCulloch (2008.) te Bartolini i Sarracino (2014.). Oishi i Kesebir (2015.) ističu da nejednakost može ublažiti utjecaj dohotka na nacionalnu sreću pa čak i da zbog nejednakosti rast dohotka može biti u negativnoj vezi sa srećom.

Naravno, sam dohodak ne može biti jedini faktor koji utječe na percepciju sreće pa valja tragati i za drugim varijablama. Oswald (1997.) je istaknuo važnost politika koje će smanjiti mogućnost gubitka radnih mjesta. Frey i Stutzer (2002.a) ističu da veća nezaposlenost i inflacija imaju negativan efekt na sreću, ali joj mogu pridonijeti institucionalni faktori poput efikasnosti i stabilnosti vlade, vladavine prava i kontrole korupcije ${ }^{31}$. Prema njihovim zaključcima institucije koje olakšavaju da se pojedinci uključe u politiku (poput referenduma) imaju puno veći utjecaj na sreću u odnosu na dohodak. (Di Tella, MacCulloch i Oswald, 2003.) su utvrdili da nezaposlenost narušava sreću, ali to kompenziraju veće beneficije za nezaposlene. Layard (2005.) ističe da obiteljske okolnosti, zaposlenost i zdravlje imaju daleko veći utjecaj na kvalitetu života i osjećaj sreće od novca, odnosno dohotka. Malešević-Perović, Mihaljević-Kosor i Filipić (2011.) su istražili važnost religijskih čimbenika na zadovoljstvo životom i zaključili da su kršćani najzadovoljniji, a da ih slijede muslimani i hindusi. Međutim, najzadovoljnijom skupinom među kršćanima su se pokazali katolici dok među muslimanima najveće zadovoljstvo iskazuju suniti. Layard, Clark i Senik (2012. ) kao važne faktore sreće, pored dohotka, ubrajaju i zaposlenost i uvjete na poslu, povjerenje, slobodu, slobodu, vrijednosti, mentalno i fizičko zdravlje, bračni status, obrazovanje, spol i godine. Bartolini i Sarracino (2014.) pokazuju da se utjecaj BDP-a na ljudsku sreću tijekom vremena smanjuje u korist društvenog kapitala. Dakle, BDP je značajan u kratkom roku, a u dugom je važniji društveni kapital. Neki autori (npr. Dunn i Norton, 2014.) smatraju kako ljude više usrećuje kad pomognu drugima (poklonom ili davanjem novca u dobrotvorne svrhe) nego da kupe nešto za sebe, a da ih najviše veseli potrošiti novac na druženje sa prijateljima. Gilovich i Kumar (2015.) pokazuju da kupnje na temelju iskustva više pridonose sreći nego materijalne kupnje.

Neka su istraživanja provedena i na uzorku posttranzicijskih zemalja. Već slike 1, 4, 7 i 11 upućuju na zaključak da je razina sreće u Hrvatskoj i posttranzicijskim članicama EU na nešto nižoj razini nego u „starim članicama“ EU. Prvo

${ }^{31}$ Navedeni je rad preglednog karaktera, pa zainteresirane upućujemo na radove prezentirane u njemu. Slični su zaključci navedeni i u Frey i Stutzer (2002.b). 
istraživanje koje je istraživalo zadovoljstvo životom u više posttranzicijskih ze-

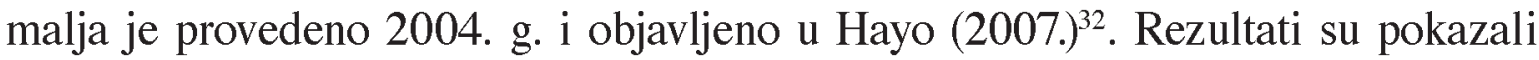
da „temeljne" socio-demografske i ekonomske varijable relevantne u istraživanju zapadnih zemalja (godine starosti - U distribucija, pozitivni učinci dohotka, obrazovanja i braka a negativan nezaposlenosti) na sličan način utječu i na sreću u posttranzicijskim zemljama. Ruralno stanovništvo je iskazalo veće zadovoljstvo životom od urbanog dok je utjecaj religije specifičan - dok sama religijska uvjerenja ne utječu značajno na sreću, dotle ju znatno povećavaju posjeti crkvama. Utjecaj ,temeljnih“ varijabli je potvrđen i u Hayo i Seifert (2003.), ali on isključuje bračni status i starost a postoji U - distribucija. Rad je, međutim, bio fokusiran samo na rani period tranzicije (1991.-1995.) i samo na ekonomsku dobrobit kao jednu podkomponentu zadovoljstva životom. No, rezultati pokazuju i da subjektivno zadovoljstvo ne može biti dobro obuhvaćeno indikatorima temeljenim na nacionalnim računima (poput BDP-a). Easterlin (2009.) ističe da je smanjenje BDP-a i zaposlenosti utjecalo na smanjenje sreće, ali da je stagnacija na tržištu rada spriječila porast sreće u uvjetima kad se BDP oporavljao ${ }^{33}$. Djankov, Nikolova i Zilinsky (2016.) su potvrdili postojanje jaza sreće (engl. happiness gap) u zemljama Istočne Europe i povezali ga sa problemom korupcije i lošim performansama vlade. Takvi rezultati navode na zaključak da se tranzicija sa planskog modela, barem u psihologiji ljudi, još nije u potpunosti završila. Utjecaj državnih izdataka na sreću u tranzicijskim zemljama su istraživale i Malešević-Perović i Golem (2010.) i zaključile da se o njima više brinu uspješne žene nego neuspješni muškarci. Nezaposlenost i BDP po stanovniku nisu bile signifikantne dok je pozitivan utjecaj inflacije bio iznenađujući. Takvi zaključci se donekle kose sa onim dobivenim u Malešević-Perović (2008.) gdje je potvrđen značaj makroekonomskih varijabli inflacije, nezaposlenosti i BDP-a (i njegovog rasta). Budući da je u svijesti ljudi znatno važniji utjecaj nezaposlenosti nego inflacije, zaključak je autora da bi više truda trebalo uložiti u obuzdavanje nezaposlenosti umjesto obuzdavanja inflacije. Važnost zaposlenosti na materijalnu dobrobit i sreću u posttranzicijskim zemljama je potvrđena i u Družić i Majstorović (2017.).

Međutim, nema mnogo istraživanja koja se bave srećom i zadovoljstvom životom samo na hrvatskim podacima čemu pridonosi i nedostatak relativno dugih serija. Prezentirani podaci u ovom radu pokazuju da se Hrvate ne može ubrojiti

${ }^{32}$ Postoje istraživanja na pojedinačnim zemljama poput Mađarske, Slovenije, Kirgistana i Rusije i Rumunjske (Hayo, 2007.).

${ }^{33}$ Primjer Njemačke navodi na nešto drukčiji zaključak. Tamo je pred ujedinjenje došlo do pada ekonomske aktivnosti i zadovoljstva kvalitetom života u istočnoj Njemačkoj, ali je osjećaj zadovoljstva počeo rasti prema kraju 1990-ih. U zapadnom dijelu Njemačke je prije ujedinjenja zadovoljstvo bilo konstantno, ali je došlo do umjerenog smanjenja nakon ujedinjenja (Easterlin i Plagnol, 2008.). 
među sretnije narode. Negativna dinamika NIS-a (a u određenoj mjeri i HIO indeksa) upućuje na zaključak da su razina i onako osrednjeg stupnja životnog zadovoljstva u uvjetima krize bila i manja. Međutim, istraživanje Kaliterna-Lipovčan i Prizmić-Larsen (2006.) pokazuje da je prema procjenama subjektivnog blagostanja Hrvatska slična zemljama pri dnu EU-15 ili pri vrhu europskih posttranzicijskih zemalja (barem u pretkriznom vremenu), te su ispitanici istaknuli da su najnezadovoljniji materijalnim stanjem, a najzadovoljniji obiteljskim životom i životom sa prijateljima. Kaliterna-Lipovčan, Brkljačić, i Šakić (2007.) istražuju razlike u subjektivnom zadovoljstvu ovisno o različitim dohocima pa se potvrdilo i da su oni sa većim dohotkom sretniji i zadovoljniji sa svojim životom, materijalnim statusom, zdravljem, postignućima, budućom sigurnosti, ekonomskom situacijom, stanju okoliša i socijalnim uvjetima u Hrvatskoj. Malešević-Perović (2010.) nalazi na podacima za 1999. g. da je zadovoljstvo životom bilo veće kod osoba u braku, zaposlenih i onih koji ostvaruju mjesečni dohodak između 5001 i 8000 kuna. Krivulja zadovoljstva životom prema dobi ima U oblik i minimum oko 50. godine, a slaba je korelacija sa obrazovanjem. Postoje razlike u zaključcima kad se promatraju podaci za 2006. g. pa su, uz osobe u braku, zaposlene i one sa većim dohotkom, veće zadovoljstvo životom iskazivali i oni sa fakultetskom naobrazbom, ali i oni koji su izvan radne snage dok U krivulja ima minimum u 58. godini. Rezultati obje godine upućuju na zaključak da zadovoljstvo životom u Hrvatskom raste sa većim BDP-om po glavi stanovnika.

\section{Zaključak}

U razmišljanjima ekonomista i filozofa zadovoljstvo pojedinaca ima važno mjesto još od pojave utilitarista u 18. stoljeću. No, dugo vremena se ono poistovjećivalo sa kupnjom dobara i usluga što je raspoloživi dohodak nametalo za važnog indikatora individualnog zadovoljstva, a BDP (po stanovniku) za važnog indikatora zadovoljstva na nacionalnoj razini. Nesavršenost BDP-a kao indikatora zadovoljstva (pa čak i kada je materijalna zadovoljština važan faktor kvalitete života) se ogleda u tome što postoji niz kvalitativnih čimbenika koji mogu unaprijediti kvalitetu života a koji se ne mogu tržišno vrednovati niti iskazati u novčanoj protuvrijednosti. Empirijska su istraživanja već pokazala da su, u danoj jedinici vremena, sretnije one zemlje koje imaju veći dohodak, ali da ne postajemo sretniji kako postajemo bogatiji. Navedena činjenica, poznata kao Easterlinov paradoks, postaje još očitija kad više dokolice, te dug i zdrav život značajno ne pridonosi sreći ljudi na Zapadu već rastu kriminal i depresija. Paradoks je najlakše objasniti hipotezom relativnog dohotka - $\mathrm{s}$ jedne strane pojedinac u određenoj zemlji postaje sretniji što 
je bogatiji i zato većina ljudi želi biti bogata, ali istovremeno, kada cijela društva postanu bogata, izgleda da nitko ne postaje nimalo sretniji. Pojedini znanstvenici stoga pokušavaju konstruirati indikator koji će bolje prikazivati kvalitetu života nego što to čini BDP po stanovniku, a unapređenje sreće postaje i važno političko pitanje pa pri kreiranju javnih politika (koje se tiču obrazovnog, zdravstvenog i moralnog sustava te zakonodavstava o obitelji i radu i sl.) treba odabrati one koje do maksimuma povećavaju ukupno zadovoljstvo i smanjuju nejednakost u prihodima unutar zemlje i među zemljama (Akerlof i Kranton, 2010.).

Prezentirani indikatori kvalitete života se odnose na HDI indeks, indeks srece prema sveučilištu Erasmus, indeks prosperiteta britanskog instituta Legatum te WHI indeks. Oni pokazuju da su zemlje sa najvećom kvalitetom života ujedno i najbogatije zemlje svijeta, a najsiromašnije one sa najnižom kvalitetom života. To nije neobično, a na to upućuje i ,prvi dio“ Easterlinovog paradoksa. Naša pojednostavljena analiza je pokazala da vezu između realnog BDP-a po stanovniku (neovisno o tome mjeri li ga se standardnim načinom ili prema paritetu kupovne moći) i sreće treba tražiti u zemljama sa visokim dohotkom. Ovdje nismo ulazili u smjer te veze jer je sigurno da zadovoljni ljudi sa većom produktivnošću pridonose i većem BDP-u (po stanovniku). Zadovoljstvo stupnjem života trebalo bi biti veće u zemljama koje ostvaruju veći dohodak.

U određivanju faktora koji utječu na sreću poslužili smo se već objavljenim istraživačkim radovima. Oni pokazuju da, osim dohotka, važan faktor sreće mogu biti i makroekonomske varijable poput (ne)zaposlenosti i inflacije, institucionalni faktori, bračno stanje, zdravlje, religijski faktori, želja da se pomogne drugima i drugi razlozi. Stoga u temeljne postulate javnih politika treba postaviti manju nezaposlenost, a veću sigurnost radnih mjesta te osigurati adekvatnu opću razinu plaća i mirovina.

Predočeni indikatori upućuju na zaključak da su posttranzicijske ekonomije (nove članice EU) manje sretne u odnosu na „stare članice“ (EU-15 bez mediteranskih zemalja). Međutim, pozicija Hrvatske varira ovisno o indikatoru. Tako spada u skupinu zemalja sa jako visokim HDI-em iako je, u usporedbi sa ostalim članicama EU, na začelju. Prema Erasmusu položaj Hrvatske prema sreći je u sredini „novih članica“ EU dok je ona prema Legatumu i WHI indeksu među najmanje uspješnim članicama EU. Svi ovi pokazatelji ne upućuju na Hrvate kao naročito sretnu i prosperitetnu naciju. Slični se zaključci mogu izvući i kad se prate Hendalov indeks optimizma (HIO) i Nacionalni indeks sreće (NIS) prema kojima su Hrvati blagi pesimisti ili osrednji optimisti. Glavni faktori koji utječu na pesimizam Hrvata tiče se gospodarskih prilika. Kod testiranja NIS-a se pokazalo da su izuzetno zadovoljni odnosima s bliskim ljudima (obitelj, prijatelji) te poslom i uvjetima na poslu, ali ne i državom. No nisu zadovoljni sa stupnjem zadovoljenja osobnih potreba što je povezano sa nedostatkom sredstava odnosno gospodarskom 
situacijom. NIS je bio koristan kako za znanstvenu analizu tako i za nositelje ekonomske politike i općenito nositeljima vlasti jer nam otvara pitanja kako poboljšati sreću Hrvata u onim komponentama gdje njihovi subindeksi poprimaju relativno niske odnosno ispodprosječne vrijednosti. To je omogućilo i davanje odgovora na mnoga pitanja poput: Kako poboljšati vlast? Kako stimulirati mlade da ostanu u Hrvatskoj i grade društvo umjesto da se isele? Kako potaknuti Dalmatince da postanu ekološki svjesniji? Da li su Hrvati iskazali zadovoljstvo poslom i uvjetima na poslu samo zato što imaju posao ili su radni uvjeti u Hrvatskoj zaista bolji negoli u susjednim zemljama?

Zaključci dosadašnjih istraživanja idu u smjeru da na osjećaj sreće i životnog zadovoljstva do određene razine utječe dohodak, ali nakon nje znatno su važniji zdravlje, obiteljski odnosi i odnosi s prijateljima. Shodno tome, ni odnos BDP-a i sreće nije linearan već pokazuje da nakon nekog praga BDP-a povećanje materijalnog blagostanja u nekoj državi/društvu ne dovodi do porasta sreće.

\section{Literatura:}

Ahlin, C. i Jiang, N. (2008.). Can micro-credit bring development? Journal of Development Economics, 86(1), str. 1-21.

Akerlof, G. i Kranton, R. (2010.). Identity Economics: How our identities shape our work, wages and well-being. Princeton: Princeton University Press.

Anand, P. (2016.). Happiness Explained: What human flourishing is and what we can do to promote it. Oxford University Press.

Bandura, R. (2008.). A Survey of Composite Indices Measuring Country Performance: 2008 Update . New York : United Nations Development Programme.

Bartolini, S. i Sarracino, F. (2014.). Happy for How Long? How Social Capital and GDP relate to Happiness over Time. Ecological Economics, 108(1), str. 242-256.

Bayles, M. D. i Henley(eds), K. (1989.). Right Conduct: Theories and Applications. New York: Random House.

Bernanke, B. S. (08.. 05. 2010.). Economics of Happiness. Preuzeto 08. 062015 iz Board of Guvernors Federal Reserve System: https://www.federalreserve.gov/newsevents/ speech/bernanke20100508a.htm

Bićanić, I. (2010.). Banka, Hendal i Allianz predstavili Nacionalni indeks sreće. Preuzeto 24.. rujna 2015. iz http://www.banka.hr/vijesti/banka-hendal-i-allianz-predstavilinacionalni-indeks-srece.

Bićanić, I., Deskar-Škrbić, M. i Tuđa, D. (2013). Ekonomska analiza dugog roka: modeli i primijenjena analiza sa posebnim osvrtom na Hrvatsku. Zagreb: neobjavljena skripta. 
Blanchflower, D. G. i Oswald, A. J. (2004.). Well-being over time in Britain and the USA. Journal of Public Economics, 88(7-8), str. 1359-1386.

Clark, A. E., Frijters, P. i Shields, M. (2008.). Relative Income, Happiness and Utility: An Explanation for the Easterlin Paradox and Other Puzzles. Journal of Economic Literature, 46(1), str. 95-144.

Deaton, A. (2008.). Income, Health and Well-Being aroung the World: Evidence from the Gallup World Poll. Journal of Economic Perspectives, 22(2), str. 53-72.

Di Tella, R. i MacCulloch, R. (2008.). Gross national happiness as an anwer to the Easterlin Paradox. Journal of Development Economics, 86(1), str. 22-42.

Di Tella, R., MacCulloch, R. J. i Oswald, A. J. (2003.). The Macroeconomics of Happiness. The Review of Economics and Statistics, 85(4), str. 809-827.

Dick, W. i Šubić, A. (07.. 12. 2012.). Blagostanje je nešto više od gospodarskog rasta. Deutsche Welle. Preuzeto 07.. 06. 2015. iz http://www.dw.com/hr/blagostanje-jene\%C5\%A1to-vi\%C5\%A1e-od-gospodarskog-rasta/a-16434991

Djankov, S., Nikolova, E. i Zilinsky, J. (2016.). The Happiness Gap in Eastern Europe. Journal of Comparative Economies, 44(1), str. 108-124.

Dolan, P., Layard, R. i Metcalfe, R. (2011.). Measuring Subjective Wellbeing for Public Policy: Recommendations on Measures. Centre for Economic Performance(23), str. $1-20$.

Došen, I. (2010.). Butan: Posljednje utočište spokoja i sreće. Banka, 16(8), str. 46-51.

Došen, I. i Ralašić, M. (travanj 2010.). Što znači 63.8? Banka, 16(4), str. 30-36.

Družić, M. i Majstorović, M. (2017.). Material Well-Being and Happiness in Transition Countries. Zagreb International Review of Economics \& Business, 20(2), str. 21-32.

Dunn, E. i Norton, M. (2014.). Happy Money - The Science of Happier Spending. Simon \& Schuster.

Easterlin, R. (1974.). Does Economic Growth Improve the Human Lot? Some empirical evidence. U P. A. David i M. W. Reder, Nations and Households in Economic Growth: Essays in Honor of Moses Abramowitz (str. 89-125). New York: Academic Press, Inc.

Easterlin, R. (1995.). Will raising the incomes of all increase the happiness of all? Journal of Economic Behavior \& Organization, 27(1), str. 35-47.

Easterlin, R. (2001.). Income and Happiness: Towards a Unified Theory. Economic Journal, 111(473), str. 465-484.

Easterlin, R. (2009.). Lost in Transition: Life Satisfaction on the Road to Capitalism. Journal of Economic Behavior and Organization, 71(2), str. 130-145.

Easterlin, R. (2016.). Paradox lost. USC Dornsife Institute for New Economic Thinking Working paper(16-02), str. 1-41.

Easterlin, R. i Angelescu, L. (2009.). Happiness and Growth the World Over: Time Series Evidence on the Happiness-Income Paradox. IZA Discussion Paper(4060), str. 1-30. 
Easterlin, R. i Plagnol, A. (2008.). Life Satisfaction and Economic Conditions in East and West Germany Pre- and Post- Unification. Journal of Economic Behavior \& Organization, 68(3-4), str. 433-444.

Easterlin, R., Angelescu-McVey, L., Switek, M., Sawangfa, O. i Smith-Zweig, J. (2010.). The Happiness-income Paradox Revisited. Proceedings of the National Academy of Sciences, 107(52), str. 22463-22468.

Esposito, G., Barcaccia, B., Matarese, M., Bertolaso, M., Elvira, M. i De Marinis, M. G. (2013). Defining Quality of Life: A Wild-Goose Chase? Europe's Journal of Psychology, 9(1), str. 185-203.

Frajman-Ivković, A. (2016.). Limitations of the GDP as a Measure of Progress and Wellbeing. Ekonomski vjesnik/Econviews, 29(1), str. 257-272.

Frajman-Ivković, A., Ham, M. i Mijoč, J. (2014.). Measuring Objective Well-Being and Sustainable Development Management. Journal of Knowledge Management, Economics and Information Technology, 4(2), str. 1-29.

Frey, B. S. i Stutzer, A. (2002.a). What Can Economists Learn from Happiness Research? Journal of Economic Literature, 40(2), str. 402-435.

Frey, B. S. i Stutzer, A. (2002.b). Happiness and Economics: How the Economy and Institutions Affect Human Well-Being. Princeton University Press.

Galić, Z. (2010.). Radim, dakle jesam. Banka, 16(11), str. 58-60.

Gilovich, T. i Kumar, A. (2015.). We'll Always Have Paris: The Hedonic Payoff from Experiental and Material Investments. Advances in Experimental Social Psycho$\log y, 57(1)$, str. 147-187.

Goossens, Y., Mäkipää, A., Schepelmann, P., van de Sand, I., Kuhndt, M. i Herrndorf, M. (2007.). Alternative progress indicators to Gross Domestic Product (GDP) as a means towards sustainable development. European Parliament: Policy Department - Economic and Scientific Policy.

Hagerty, M. R. i Veenhoven, R. (2003.). Wealth and Happiness Revisited - Growing National Income Does Go with Greater Happiness. Social Indicators Research, 64(1), str. 1-27.

Hajdari, A. (2013.a). Važno je biti zaposlen. Banka, 19(4), str. 73.

Hajdari, A. (2013.b). Kakvu budućnost očekuju Hrvati? Banka, 19(7), str. 75.

Hajdari, A. (2014.). Hrvati sve zabrinutiji. Banka, 20(8), str. 57.

Hanson, R. (september 2013.). Hardwiring Happiness: The New Brain Science of Contentment, Calm and Confindence. New York: Harmony Books.

Hayo, B. (2007.). Happiness in transition: An empirical study on Eastern Europe. Economic systems, 31(2), str. 204-221.

Hayo, B. i Seifert, W. (2003.). Subjective well-being in Eastern Europe. Journal of Economic Psychology, 24(3), str. 329-348.

Helliwell, J., Layard, R. i Sachs(ur.), J. (2016.). World Happiness Report. United Nations. 
Hendalov indeks optimizma. (razna izdanja). Preuzeto 30.. kolovoza 2017. iz Hendal: www.hendal.hr

Humpert, S. (2010.). A Note on Happiness in Eastern Europe. European Research Studies, 13(3), str. 133-144.

Jorgenson, D. i Schreyer, P. (2015.). Measuring Individual Economic Well-Being and Social Welfare within the Framework of the System of National Accounts. OECD/ IARIW Conference on the Future of National Accounts (str. 1-31). Paris: OECD.

Kahneman, D. (2011.). Misliti brzo i sporo. Zagreb: Mozaik knjiga (prijevod).

Kahneman, D. i Krueger, A. B. (2006.). Developments in the Measurement of Subjective Well-Being. Journal of Economic Perspective, 20(1), str. 3-24.

Kahneman, D., Krueger, A. B., Schkade, D., Schwartz, N. i Stone, A. (2006.). Would You Be Happier If You Were Richer? A Focusing Illusion. Science, 312(5782), str. 1908-10.

Kaliterna-Lipovčan, L. i Prizmić-Larsen, Z. (2006.). Kvaliteta življenja, životno zadovoljstvo i osjećaj sreće u Hrvatskoj i europskim zemljama. U K. Ott(ur.), Pridruživanje Hrvatske Europskoj Uniji: izazovi sudjelovanja. Institut za javne financije i Friedrich Ebert Stiftung.

Kaliterna-Lipovčan, L., Brkljačić, T. i Šakić, V. (2007.). Monthly income and Subjective Well-being of Croatian Citizens. Croatian Medical Journal, 48(5), str. 727-733.

Kalmijn, W. (2015.). Methods for Measurement of Happiness. Preuzeto 30.. kolovoza 2017. iz World Database of Happiness: https://worlddatabaseof happiness.eur.nl/ hap_quer/introtext_measures3.pdf

Layard, R. (2005.). Happiness: Lessons from a New Science. Penguin.

Layard, R., Clark, A. i Senik, C. (2012. ). The Causes of Happiness and Misery. U J. Helliwell, R. Layard i J. Sachs(eds.), World Happiness Report (str. 58-89). The Earth Institute.

Legatum institute. (2016.). The Legatum Prosperity Index. Preuzeto 30.. kolovoza 2017. iz www.prosperity.com/rankings?pinned=NZL\&filter $=$.

Malešević-Perović, L. (2008.). Subjektivno ekonomsko zadovoljstvo u tranzicijskim zemljama: istraživanje relativne važnosti makroekonomskih varijabli. Financijska teeorija i praksa, 32(4), str. 523-542.

Malešević-Perović, L. (2010.). Life satisfaction in Croatia. Croatian Economic Survey, 12(1), str. 45-81.

Malešević-Perović, L. i Golem, S. (2010.). Investigating Macroeconomic Determinants of Happiness in Transition Countries: How Important is Government Expenditure. Eastern European Economics, 48(4), str. 59-75.

Malešević-Perović, L., Mihaljević-Kosor, M. i Filipić, P. (2011.). The relative importance of religious denominations for life satisfaction. Journal of Applied Economics and Business Research, 1(3), str. 162-176.

Nacionalni indeks sreće. (razna izdanja). Preuzeto 07.. lipnja 2015. iz Hendal: www.hendal.hr 
Nikolova, E. i Sanfey, P. (2015.). How musch should we trust life satisfaction data? Evidence from the Life in Transition Survey. EBRD Working Papers(174).

Oishi, S. i Kesebir, S. (2015.). Income inequality explains why economic growth does not always translate to an increase in happiness. Psichological science, 26(1), 1630-1638.

Oswald, A. J. (1997.). Happiness aand Economic Performance. Economic Journal, 107(1997)(445), str. 1815-1831.

Ralašić, M. (2012.a). Dividenda sreće. Banka, 18(2), str. 66-68.

Ralašić, M. (2012.b). Obitelj i prijatelji podižu sreću. Banka, 18(5), str. 48-50.

Ralašić, T. (2015. ). Ekonomija sreće - završni rad. Zagreb: Ekonomski fakultet.

Robbins, L. (1932.). An Essay on the he Nature and Significance of Economic Science. London: Macmillan.

Sacks, D., Stevenson, B. i Wolfers, J. (2010. ). Subjective Well-Being, Income, Economic Development and Growth. Federal Reserve Bank of San Francisco Working Paper Series(2010-28), str. 1-51.

Samuel, H. (14.. 09. 2009.). Nicolas Sarkozy wants to measure economic success in "happiness'. The Telegraph. Preuzeto 07.. 06. 2015 iz http://www.telegraph.co.uk/news/ worldnews/europe/france/6189530/Nicolas-Sarkozy-wants-to-measure-economicsuccess-in-happiness.html

Schepelmann, P., Goossens, Y. i Makipaa, A. (2010.). Towards Sustainable Development Alternatives to GDP for measuring progress (Svez. Wuppertal Spezial 42). Wuppertal: Wuppertal Institute for Climate, Environment and Energy.

Stevenson, B. i Wolfers, J. (2008.). Economic Growth and Subjective Well Being; Reassessing the Easterlin paradox. Brookings papers on Economic Activity, 2008(1), str. 1-87.

Stiglitz, J. E., Sen, A. K. i Fitoussi, J.-P. (2010.). Mismeasuring Our Lives. The New Press.

UN. (19.. July 2011.). General Assembly Resolutions. Preuzeto 10.. July 2015. iz Resolutions adopted by the General Assembly at its 65th session: http://www.un.org/en/ga/ search/view_doc.asp?symbol=A/RES/65/309

UNDP. (2016.a). Human Development Report. United Nations Development Programme.

UNDP. (2016.b). Human Development Report - Technical notes. Dohvaćeno iz hdr.undp. org>hdr2016_technical_notes: hdr.undp.org>hdr2016_technical_notes

UNECE/OECD/Eurostat. (2008.). Measuring Sustainable Development. New York and Geneva: United Nations.

University of Toronto. (29.. 11. 2011.). G20 Information Centre. Dohvaćeno iz G20 Leaders Statement: The Pittsburgh Summit September, 24-25, 2009: www.g20.utoronto.ca/2009/2009communique0925.html

Ura, K., Alkire, S. i Zangmo, T. (2014.). Case Study: Bhutan - Gross National Happiness anf GNH Index. U J. Helliwell, R. Layard i J. Sachs. (eds.), World Happiness Report (str. 108-158).

Veenhoven, R. (2015.a). World Database of Happiness, Erasmus University. Preuzeto 30.. kolovoza 2017. iz Happiness in Nations: http://worlddatabaseof happiness,eur.nl/ hap_nat/nat_fp.php?mode=1 
Veenhoven, R. (2015.b). Concept of Happiness. Preuzeto 30.. kolovoza 2017. iz World Database of Happiness: https://worlddatabaseof happiness.eur.nl/hap_quer/introtext_measures2.pdf

Vehovec, M. (2011.). Mitovi o sreći. Banka, 17(1), str. 58-60.

Wai-kit, L. (5.. 11. 2013.). S'pore needs both financial and 'social' reserves to thrive: President Tony Tan. Today. Preuzeto 07.. 06. $2015 \mathrm{iz} \mathrm{http://www.todayonline.com/singa-}$ pore/spore-needs-both-financial-and-social-reserves-thrive-president-tony-tan

Winnett, R. (25.. 11. 2010.). David Cameron: I want to make people feel better. The Telegraph. Preuzeto 07.. 06. $2015 \mathrm{iz} \mathrm{http://www.telegraph.co.uk/news/politics/david-ca-}$ meron/8158015/David-Cameron-I-want-to-make-people-feel-better.html

Yunus, M. (2009.). Za svijet bez siromaštva. Zagreb: VBZ.

\section{Dodaci}

Tablica 4

\section{ALTERNATIVNI OBJEKTIVNI POKAZATELJI DOBROBITI}

\begin{tabular}{|c|c|c|}
\hline \multicolumn{3}{|c|}{ Pokazatelji koji... } \\
\hline ... korigiraju BDP & ...zzamjenjuju BDP & ....nadopunjuju BDP \\
\hline $\begin{array}{l}\text { - Mjera ekonomskog } \\
\text { blagostanja (engl. Measure } \\
\text { of Economic Welfare - } \\
\text { MEW) } \\
\text { - Indeks održivog } \\
\text { ekonomskog blagostanja } \\
\text { (engl. The Index of } \\
\text { Sustainable Economic } \\
\text { Welfare - ISEW) } \\
\text { - Izvorni indikator napretka } \\
\text { (engl. Genuine Progress } \\
\text { Indicator-GPI) } \\
\text { - Zeleni BDP (engl. Green } \\
\text { GDP) } \\
\text { - Izvorna štednja - } \\
\text { prilagodena neto štednja } \\
\text { (engl. Genuine Savings } \\
\text {-Adjusted Net Savings) }\end{array}$ & $\begin{array}{l}\text { - Indeks razvoja ljudskog } \\
\text { kapitala (engl. Human } \\
\text { Development Index-HDI) } \\
\text { - Ekološki trag - (engl. } \\
\text { Ecological Footprint - EF) } \\
\text { - Indeks planetarne sreće (engl. } \\
\text { Happy Planet Index - HPI) } \\
\text { - Indeks održivosti u okolišu } \\
\text { (engl. Environmental } \\
\text { Sustainability Index -ESI) } \\
\text { - Indeks performansi u } \\
\text { okolišu (engl. Environmental } \\
\text { Performance Index - EPI) } \\
\text { - Indeks regionalne kvalitete } \\
\text { razvoja (engl. Regional } \\
\text { Quality of Development } \\
\text { Index) }\end{array}$ & $\begin{array}{l}\text { - Sustav ekonomskih računa u okolišu (engl. System } \\
\text { of Economic Environmental Accounts - SEEA) } \\
\text { - Matrica nacionalnog računovodstva koja uključuje } \\
\text { račune u okolišu (engl. National Accounting } \\
\text { Matrix including Environmental Accounts - } \\
\text { NAMEA) } \\
\text { - Njemačko ekonomsko računovodstvo u okolišu } \\
\text { (engl. German Environmental Economic } \\
\text { Accounting - GEEA) } \\
\text { - Sistem ekonomskih i društvenih računa i } \\
\text { proširenja (engl. System of Economic and Social } \\
\text { Accounting matrices and Extensions - SESAME) } \\
\text { - Održivi razvojni indikatori - (engl. Sustainable } \\
\text { Development Indicators -SDI) } \\
\text { - Indikatori razdvajanja (engl. Decoupling } \\
\text { indicators) } \\
\text { - Indikatori političkih i civilnih sloboda (engl. } \\
\text { Political and civil freedom indicators - Freedom } \\
\text { House, US) } \\
\text { - Milenijski razvojni ciljevi (engl. Millennium } \\
\text { Development Goals - MDGs) }\end{array}$ \\
\hline
\end{tabular}

Izvor: Načinjeno na temelju: Schepelmann, Goossens i Makipaa (2010.). 


\section{Tablica 5}

\section{KOMPONENTE NACIONALNOG INDEKSA SREĆE}

\begin{tabular}{|c|c|}
\hline Komponente NIS-a & Što komponenta prati \\
\hline \multicolumn{2}{|l|}{$\begin{array}{l}\text { Opće zadovoljstvo } \\
\text { Životnom situacijom }\end{array}$} \\
\hline \multicolumn{2}{|l|}{$\begin{array}{l}\text { Procjena općeg } \\
\text { zadovoljstva životnom } \\
\text { situacijom za } 2 \text { godine }\end{array}$} \\
\hline $\begin{array}{l}\text { Emotivno stanje na } \\
\text { osnovu doživljenih } \\
\text { emocija }\end{array}$ & $\begin{array}{l}\text { Uključuje } 10 \text { elemenata: smijeh, poštovanje, užitak, sreću, zabrinutost, tugu, ljutnju, stresa, ljubavi } \\
\text { i novost. Mjeri se identificiranjem pozitivnih ili negativnih emocija koje su ispitanici doživjeli u } \\
\text { kraćem vremenskom periodu prije ispitivanja. Vrijednost ove komponente } 0 \text { znači da su svi ispitani } \\
\text { tijekom kraćeg vremenskog razdoblja doživjeli isključivo negativne emocije, a vrijjednost } 100 \text { da su } \\
\text { svi ispitani tijekom kraćeg vremenskog razdoblja doživjeli iskjjučivo pozitivne emocije. }\end{array}$ \\
\hline Zdravo ponašanje & $\begin{array}{l}\text { Uključuje } 5 \text { elemenata: pušenje, konzumaciju alkohola, svježeg voća i povrća, te brze i teške hra- } \\
\text { ne i fizičku aktivnost. Mjeri se identificiranjem pozitivnih (npr. tjelesna aktivnost) i negativnih } \\
\text { (npr. pušenje) ponašanja koja su povezana s zdravljem, a koja ispitanici čine (u većoj ili manjoj } \\
\text { mjeri) ili ne čine. Vrijjednost ove komponente } 0 \text { znači da svi ispitani u većoj mjeri upražnjavaju } \\
\text { samo nabrojana ponašanja koja negativno utječu na zdravlje, a vrijednost } 100 \text { da svi ispitani u } \\
\text { većoj mjeri upražnjavaju samo ponašanja koja pozitivno utječu na zdravlje. }\end{array}$ \\
\hline $\begin{array}{l}\text { Uvjeti u radnoj } \\
\text { (školskoj) okolini }\end{array}$ & $\begin{array}{l}\text { Uključuje } 12 \text { elemenata: zadovoljstvo poslom, iskorištavanje potencijala na poslu, tretman od } \\
\text { nadredenih na poslu, otvorenu poslovna okolinu, fizičku radnu okolinu, međuljudske odnose na } \\
\text { poslu, zadovoljstvo školovanjem, iskorištavanje potencijala u školi, tretman od profesora, otvo- } \\
\text { renu školsku okolinu, fizički obrazovnu okolinu i međuljudske odnose u školi. }\end{array}$ \\
\hline Zdravstveno stanje & $\begin{array}{l}\text { Uključuje } 10 \text { elemenata: procjenu tjelesne težine, stanje bolesti, prisutnost na poslu /u školi, } \\
\text { fizičke bolove, kroničnu bolest, poteškoće spavanja, poteškoće apetita, poteškoće u odnosima, } \\
\text { raspoloženje i poteškoće u svakodnevnim aktivnostima. Mjeri se postojanjem ili odsustvom bo- } \\
\text { lesti ili zdravstvenih tegoba, odlascima na bolovanje, zdravstvenim poteškoćama. Vrijednost ove } \\
\text { komponente } 0 \text { znači da su svi ispitani u vrlo lošem zdravstvenom stanju a } 100 \text { potpuno odsustvo } \\
\text { bolesti i zdravstvenih tegoba kod svih ispitanih. }\end{array}$ \\
\hline $\begin{array}{l}\text { Pristup osnovnim } \\
\text { potrebama }\end{array}$ & $\begin{array}{l}\text { Uključuje } 7 \text { elemenata: dostupnost i kvaliteta pitke vode, susjedstvo, raspoloživu količinu novca } \\
\text { za hranu, stanovanje, odjeću i obuću, te za "male luksuze" i dostupnost zdravstvenih usluga. }\end{array}$ \\
\hline Ekološko ponašanje & $\begin{array}{l}\text { Uključuje } 7 \text { elemenata: korištenje javnog prijevoza ili bicikla umjesto automobila, razdvajanje } \\
\text { organskog otpada od neorganskog, odvajanje/odnošenje PVC ili staklene ambalaže, korištenje } \\
\text { štednih žarulja, dobrovoljno čišćenje prirode, skupljanje i posebno odlaganje starog papira i } \\
\text { štedljivo korištenje vode. Mjeri se identificiranjem ekološki svjesnih ponašanja koja ispita- } \\
\text { nici provode ili ne, u većoj ili manjoj mjeri, kao što su razdvajanje otpada i štednja energije. } \\
\text { Vrijednost ove komponente } 0 \text { znači da se nitko od ispitanih uopće ne ponaša na ekološki svjestan } \\
\text { način, a vrijednost } 100 \text { značila da se svi ispitani u većoj mjeri ponašaju na ekološki svjestan } \\
\text { način po svim zadanim kriterijima }\end{array}$ \\
\hline $\begin{array}{l}\text { Zadovoljstvo osobnim } \\
\text { razvojem i socijalnom } \\
\text { okolinom }\end{array}$ & Uključuje 4 elementa: osobni razvoj, obitelj i prijatelje, mjesto življenja i državu. \\
\hline
\end{tabular}

Izvor: Nacionalni indeks sreće, razna izdanja (dostupno na: www.hendal.hr), Ralašić (2015.) 
HAPPINESS AND ECONOMIC ACTIVITY

\begin{abstract}
Summary
Traditional macroeconomic analysis uses few "objective indicators" as life quality indicators. Among them gross domestic product (GDP) is commonly used but recently some scientists disallow adequacy of GDP in observing of life quality and happiness of population. This paper reviews literature which investigates the relationship between happiness and economic activity. Additionally, few life quality indicators are also observed (including Croatian position). Also Hendal's index of optimism (HIO) and National index of happiness (NIH) with their components are also observed which showed that Croatians does not belong to the happiest populations.
\end{abstract}

Keywords: GDP, life quality indicators, Easterlin paradox, Hendal's index of optimism, National index of happiness 